Federal Reserve Bank of New York
Staff Reports

\title{
Dealer Financial Conditions and Lender-of-Last-Resort Facilities
}

\author{
Viral V. Acharya \\ Michael J. Fleming \\ Warren B. Hrung \\ Asani Sarkar
}

Staff Report No. 673

May 2014

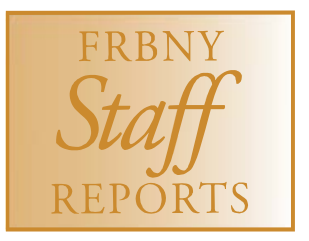

This paper presents preliminary findings and is being distributed to economists and other interested readers solely to stimulate discussion and elicit comments. The views expressed in this paper are those of the authors and do not necessarily reflect the position of the Federal Reserve Bank of New York or the Federal Reserve System. Any errors or omissions are the responsibility of the authors. 


\title{
Dealer Financial Conditions and Lender-of-Last-Resort Facilities
}

Viral V. Acharya, Michael J. Fleming, Warren B. Hrung, and Asani Sarkar

Federal Reserve Bank of New York Staff Reports, no. 673

May 2014

JEL classification: G01, G28, E58, D44

\begin{abstract}
We examine the financial conditions of dealers that participated in two of the Federal Reserve's lender-of-last-resort (LOLR) facilities--the Term Securities Lending Facility (TSLF) and the Primary Dealer Credit Facility (PDCF)--that provided liquidity against a range of assets during 2008-09. Dealers with lower equity returns and greater leverage prior to borrowing from the facilities were more likely to participate in the programs, borrow more, and--in the case of the TSLF--at higher bidding rates. Dealers with less liquid collateral on their balance sheets before the facilities were introduced also tended to borrow more. There also appear to be some interaction effects between financial performance and balance sheet liquidity in explaining dealer behavior. The results suggest that both financial performance and balance sheet liquidity play a role in LOLR utilization.
\end{abstract}

Key words: lender of last resort, central banking, crises, illiquidity, insolvency, stigma

Corresponding author: Acharya, New York University Stern School (e-mail:

vacharya@stern.nyu.edu). The authors would like to thank Douglas Diamond (discussant), Darrell Duffie, Frank Keane, Jörg Rocholl (discussant), Annette Vissing-Jorgensen (discussant) and seminar participants at the Federal Reserve Bank of New York, American Economic Association Annual Meeting (2012), European Finance Association Annual Meeting (2012), American Finance Association Annual Meeting (2013), and University of Washington for valuable feedback and suggestions. The authors would like to also thank Adam Biesenbach, Casidhe Horan and Weiling Liu for excellent research assistance. The views expressed in this paper are those of the authors and do not necessarily reflect the position of the Federal Reserve Bank of New York or the Federal Reserve System. To view the authors' disclosure statements, visit http://www.newyorkfed.org/research/author_disclosure/ad_sr673.html. 


\section{Introduction}

Central banks undertook unprecedented actions to mitigate the effects of the financial crisis of 2007-09, with the Federal Reserve acting as lender-of-last resort (LOLR) to nondepository institutions for the first time since the 1930s. Evidence has now been provided to understand ways in which central bank liquidity provision relaxes institutions' funding constraints ex post and thereby improves prices of illiquid assets. ${ }^{1}$ However, relatively little work has sought to understand the ex-ante incentives of firms to participate in the facilities and pledge specific types of collateral. In this paper, we attempt to fill this gap by studying dealer behavior in two of the Fed's LOLR facilities - the Term Securities Lending Facility (TSLF) and the Primary Dealer Credit Facility (PDCF) - that provided liquidity against a range of assets during 2008-09.

The TSLF and PDCF were introduced to address the funding pressures faced by dealers emanating from the disruptions in short-term money markets. The TSLF, announced first, enabled dealers to swap less liquid collateral for more liquid Treasury collateral at a fee determined via auction. In "Schedule 1" TSLF operations, allowable collateral was limited to Fed-eligible collateral, that is, Treasury securities, agency debt securities, and agency mortgage-backed securities (MBS). Allowable collateral for "Schedule 2" TSLF operations was broader and became more expansive over time, consisting of Schedule 1 collateral plus all investment grade debt securities after September 14, 2008. The liquid Treasury collateral obtained via the TSLF was easier to fund in the market for repurchase agreements (repo market). The PDCF, in contrast, provided funds directly to dealers at a set rate, and accepted lower quality collateral than the TSLF.

Our main finding is that the observed demand for liquidity of a dealer - as measured by the likelihood of participation in the facilities, the amount dealers sought to borrow, and the TSLF bidding rate - was greater for dealers with weaker financial conditions. Figure 1 summarizes our results, albeit informally. The figure shows dealers' average borrowing from

\footnotetext{
${ }^{11}$ See, for example, McAndrews, Sarkar, and Wang (2008), Coffey, Hrung, and Sarkar (2009), Fleming, Hrung, and Keane (2010), Adrian, Kimbrough, and Marchioni (2011), Ashcraft, Garleanu, and Pedersen (2011), Campbell, Covitz, Nelson, and Pence (2011), Wu (2011), Rose and Spiegel (2012), and DuyganBump, Parkinson, Rosengren, Suarez, and Willen (2013). Fleming (2012) reviews many of these studies.
} 
the various facilities (over the period dealers borrowed from the PDCF - from March 17, 2008 until May 12, 2009) against their average cumulative equity return from the beginning of 2007. ${ }^{2}$ For each TSLF schedule type and for the PDCF, borrowing amounts tend to be higher for firms with worse equity performance.

In our formal tests, we proxy for the financial condition of a dealer at the time of a borrowing opportunity by two measures: 1) the cumulative equity return from a pre-crisis date (January 2, 2007), as in Figure 1, and 2) the dealer's leverage, the ratio of quasi-market value of assets (market value of equity + book value of non-equity liabilities) to market value of equity. These measures are of particular interest because they reflect the market's assessment of firms' balance-sheet condition and, in particular, of their equity and equity relative to non-equity liabilities, and diverged significantly from regulatory capital levels (Haldane, 2012). We find a statistically and economically significant effect of these dealer financial conditions on demand for liquidity in the facilities and we find that the effect is robust to controlling for time fixed effects, which account for - and which we show are related to - fluctuations in aggregate funding conditions.

When we exploit the differing collateral eligibility across the two schedules of TSLF auctions, we find evidence that in Schedule 2 auctions, where permissible collateral was of lower quality (especially after the collapse of Lehman Brothers on September 15, 2008), dealers with lower equity returns were more likely to participate in auctions and sought to borrow significantly larger amounts. This suggests that dealers with weaker financial conditions found it more attractive to borrow in facilities that accepted less liquid collateral, potentially because they faced greater private funding costs for such collateral.

One explanation for our findings is that weaker dealers had more illiquid collateral to finance since solvency and liquidity problems often feed on each other (see, Rochet and Vives, 2010, and Diamond and Rajan, 2005, for example). We test for this possibility and find that dealers with greater proportions of non-Fed-eligible collateral on their balance sheet prior to the crisis were indeed more likely to borrow from the TSLF and PDCF. Moreover,

\footnotetext{
${ }^{2}$ The analysis excludes Bear Stearns, which agreed to be acquired by J.P. Morgan before either facility started operating. It also excludes Cantor Fitzgerald, which is not publicly traded. Lehman Brothers is included until its bankruptcy on September 15, 2008.
} 
we find some evidence that illiquidity and financial conditions interact, especially for participation at the PDCF - the broader of the two facilities; that is, worse performing firms are more likely to borrow from the lender of last resort when they have more illiquid collateral. $^{3}$

We also find that the demand for liquidity by a dealer was increasing in the average financial performance of all dealers at time of a TSLF auction. In other words, the effect of a decrease in the performance of a dealer in the set of bidders was to depress the participation by other dealers (and as our earlier results show, to enhance its own demand for liquidity). Because the Fed auctioned a fixed and limited amount of Treasury securities, this suggests that dealers with worse financial conditions "crowded out" dealers with better financial conditions at the TSLF. While lending through auctions has been proposed as a potential remedy for the stigma associated with central bank borrowing, the crowding-out result represents a limitation to this remedy as the greater price that weaker borrowers are prepared to pay for liquidity can deter the safer borrowers from participating. ${ }^{4}$

While the funding difficulties faced by dealers reflected the performance and liquidity of their assets, it may have also reflected the structure of their liabilities. While data limitations preclude an extensive analysis of this issue, we do examine, for a subset of dealers, the relationship between the financial condition measures we employ and the repo liabilities ratio, which is the ratio of the sum of securities sold to repurchase and fed funds borrowings to total liabilities. We focus on the period from early 2007 until the failure of Bear Stearns (as the extent of repo liabilities post-Bear Stearns would be affected by the

\footnotetext{
${ }^{3}$ When we examine further potential interaction effects between borrowing in the TSLF and PDCF, we find that dealers who borrowed heavily in one facility tended to borrow heavily in the other. We also find that firms appear to have borrowed from the PDCF mainly because they needed funds in addition to what they could obtain from the TSLF (which auctioned fixed quantities of funds), and not because they valued the flexibility of shorter-term borrowing via the PDCF.

${ }^{4}$ This "crowding-out" effect is reminiscent of the theoretical channel in the literature, e.g., Diamond and Rajan (2005), wherein banks with weaker financial conditions demand liquidity with greater immediacy, but if the pool of liquidity is limited (as in a central bank auction in our setting), then the stronger liquidity demand of weaker banks precludes banks with relatively better financial conditions from having access to liquidity or makes it costlier for these latter banks to access liquidity. Note, however, that the relative lack of participation of stronger firms does not mean that such firms did not benefit from the facility if participation of weaker firms eased funding conditions and reduced the chances of fire sales more generally. Also note that the TSLF imposed a 20\% award limit at each auction, ensuring that liquidity could be supplied to at least five dealers.
} 
TSLF and the PDCF). There appears to be a strong relationship, with worse performing dealers having higher ratios of repos to total liabilities.

Our results shed light on the lender-of-last-resort role played by central banks during aggregate liquidity shortages and panics. The associated literature suggests a trade-off between the ex-post benefits of intervention and its ex-ante costs. In his celebrated work, Lombard Street, Walter Bagehot (1873) codified the nineteenth century's collective wisdom on central bank provision of liquidity. Bagehot suggested that in times of panic, the central bank should freely advance reserves to any private bank able to offer "what in ordinary times is reckoned a good security" as collateral, but that these advances should be charged a penalty rate to discourage applications from banks that do not need it. A rationale for such intervention by a central bank is that solvent but illiquid firms may inefficiently fail or engage in liquidations and fire sales in the absence of access to the lender of last resort.

While Bagehot was concerned primarily with the practical goal of conserving limited reserves, recent literature (see, especially, Diamond and Rajan, 2005) has stressed the incentive reasons for adopting such a policy: it is not easy to tell the difference between an illiquid and an insolvent institution. In those circumstances, a central bank can easily find itself lending to an insolvent institution, perhaps delaying its timely reorganization and recapitalization. While lending at a penalty rate partially addresses this moral hazard concern, some (for instance, Acharya and Backus, 2009) have argued that central bank liquidity provision should be made conditional on adequate solvency estimates (such as maximum leverage ratio or minimum capital adequacy) of financial institutions. ${ }^{5}$ Lack of such conditionality renders the central bank's provision of LOLR to weaker financial institutions as a form of forbearance that can let the weakness of these institutions worsen, leading to "zombie banks," and further deepen the crisis. ${ }^{6}$

\footnotetext{
${ }^{5}$ Acharya and Backus (2009) draw an analogy with private lines of credit, and recommend that central banks' liquidity facilities, like private lines of credit, include a Material Adverse Change (MAC) clause that allows the lender to refuse credit if the borrower's credit quality deteriorates materially. MAC clauses are indeed invoked by banks in practice (see Sufi, 2009) for firms that violate covenants. Similarly, they recommend that central banks should verify that they are indeed lending to sound institutions.

${ }^{6}$ Evidence on the presence of such "zombie banks" lending to "zombie firms" - and inducing credit crunch on others - is documented, for instance, by Caballero, Hoshi and Kashyap (2008), in the Japanese
} 
Our analysis, by showing the linkage between the participation of dealers in LOLR facilities and their relative financial performance, provides evidence consistent with the incentive reasons for Bagehot's recommendation, though it cannot provide a full welfare analysis of the overall effect of these facilities. While Bagehot and the moral hazard literature emphasize the need for restricting participation in LOLR programs to higher quality firms, asymmetric information considerations suggest that such restrictions need not be optimal. Flannery (1996) emphasizes that, during crisis periods, credit markets might fail due to the "lemons" problem and even solvent borrowers might be rationed or squeezed out. By lending at the break-even "pooling rate," LOLR facilities provide credit to some safe borrowers at the cost of also lending to risky borrowers. Philippon and Skreta (2012) examine cost-minimizing interventions when a bank's decision to participate in LOLR facilities reveals its type to private lenders. Optimal intervention involves the central bank lending to risky borrowers. However, weaker banks might be deterred from participation if the decision creates "stigma" by providing signals of asset quality to private lenders (Ennis and Weinberg, 2013, and Philippon and Skreta, 2012). ${ }^{7}$

The rest of the paper is organized as follows. Section 2 provides background information on the PDCF and TSLF. Section 3 describes our data. Section 4 presents our main empirical results. Section 5 presents results of various additional analyses. Section 6 concludes.

banking crisis of the 1990's and attributed to forbearance and lack of required recapitalization for banks by the Bank of Japan. Acharya and Tuckman (2013) develop a model showing that relatively distressed financial firms reduce the extent of sales of illiquid collateral eligible for LOLR and shed more liquid collateral in private markets, thereby building up their "illiquid leverage", a phenomenon they confirm empirically during the crisis of 2007-08 using evidence on balance sheets and LOLR usage of brokerdealer firms (comparing the relatively more distressed Bear Stearns, Lehman Brothers and Merrill Lynch, to Goldman Sachs and Morgan Stanley).

7 Empirically, Hrung and Sarkar (2012) find that adverse selection measures such as the bid-ask spread were robust determinants of bank funding costs during the subprime and European debt crisis. Further, discount window stigma appears to have dissuaded firms from borrowing central bank liquidity during the crisis, as shown by Armantier, Ghysels, Sarkar and Shrader (2011). 


\section{The Term Securities Lending Facility and the Primary Dealer Credit Facility}

\section{A. Repo Market Conditions in 2008}

Repurchase agreements (repos) play a crucial role in the efficient allocation of capital in financial markets. They are widely used by dealers to finance their market-making, riskmanagement, and speculative activities and they provide a safe and low-cost way for mutual funds, depository institutions, and others to lend funds. The importance of the repo market is suggested by its immense size: primary dealers reported financing $\$ 4.5$ trillion in fixed income securities with repos as of March 4, 2008.

While dealers normally rely on private markets to finance their positions, such markets became severely impaired in early 2008. Lenders of funds became increasingly concerned about losing money on repos because of worries about the value of the collateral as well as the credit risk of counterparties. Lenders responded by increasing haircuts reducing the amount they were willing to lend for a given amount of collateral - and by halting lending against certain types of collateral altogether (Copeland, Martin, and Walker, 2010, 2012; Gorton and Metrick, 2012; and Krishnamurthy, Nagel, and Orlov, 2013).

Another response was for lenders to demand greater compensation for lending against riskier collateral. As shown in Figure 2, one month agency and agency MBS repo spreads to Treasury repo have historically been quite narrow, averaging 8 and 11 basis points between January 2005 and June 2007. That is, a dealer pledging agency debt securities as collateral has typically paid only slightly more interest to borrow funds than a dealer pledging Treasury securities. Such spreads widened out sharply as the financial crisis deepened, averaging 51 and 61 basis points, respectively, over January and February of 2008. Repo spreads for less liquid collateral are not widely available, but were undoubtedly wider.

Disruptions in the ability of dealers to finance themselves in the repo market compel them to seek alternative sources of funding, or to liquidate their positions. If a dealer cannot borrow elsewhere, and sales of securities are infeasible because of market illiquidity, a dealer might have to file for bankruptcy. It is widely reported that the inability of Bear Stearns to access the repo market was an important factor in its near collapse and purchase by J.P. 
Morgan Chase in March 2008 and in the subsequent failure of Lehman Brothers six months later. $^{8}$

\section{B. Introduction of the Facilities}

It was in this environment of funding market stress that the TSLF and PDCF were introduced. The TSLF, announced March 11, 2008, allowed primary dealers to bid a fee to borrow Treasury securities from the Fed for a term of 28 days, while agreeing to provide less liquid securities as collateral (see Table I). That is, collateral which may be difficult to finance could be temporarily swapped for Treasury collateral, which is easier to finance. The Fed announced it would lend up to $\$ 200$ billion in Treasury securities via this facility.

The PDCF, announced five days later, allowed primary dealers to borrow funds from the Fed on a daily basis at a set fee against designated collateral (see Table I). The PDCF was more flexible than the TSLF because it provided funds instead of Treasury collateral, because it allowed for a broader range of collateral, and because it was available on a standing basis, with no set borrowing limit. The PDCF was thus similar to the Fed's discount window, which serves as a backstop source of liquidity for depository institutions.

The new facilities increased the ability of dealers to obtain financing, especially dealers relying on the repo market for financing of less liquid collateral. The ability of dealers to obtain financing through the facilities should have reduced the need for dealers to sell assets into illiquid markets to raise capital, potentially improving the liquidity of those markets. The ability to finance through the facilities should also have reduced funding pressures on dealers, reducing the likelihood of a loss of confidence among lenders.

Note that while the TSLF was uniformly less flexible than the PDCF, its allocation of liquidity via auction may have been more effective at overcoming the perceived stigma that is thought to affect borrowing from the Fed's standing facilities (see, for example, Armantier, Ghysels, Sarkar and Shrader, 2011). The stigma arises from the concern that adverse

\footnotetext{
${ }^{8}$ See, for example, "The Bear Stearns Fallout: With Street Watching, 'Repo' Trading Is Light - Market That Turned on Bear Stearns Remains Cautious," Wall Street Journal, C6, March 18, 2008, and "TSLF Auction Could Be the Light at the End of the Repo Tunnel," Financial Times, March 27, 2008.
} 
inferences will be drawn about a firm's creditworthiness if its borrowing were to become known. ${ }^{9}$ Auction facilities may overcome this stigma because they allow dealers to approach the Fed collectively rather than individually and because borrowing rates are set at auction and not at a premium by the Fed. ${ }^{10}$

The TSLF grew quickly after its inception, with an initial auction size of $\$ 75$ billion. Figure 3 shows that the program (Schedule 1 and Schedule 2 combined) reached nearly $\$ 160$ billion outstanding within a month and peaked at the program's maximum announced size of $\$ 200$ billion in late October to early November 2008. ${ }^{11}$ As funding markets improved, utilization declined and lending under the facility wound down to zero by mid-August 2009 . Authorization for lending under the TSLF officially expired on February 1, 2010.

Unlike the TSLF, the PDCF was used sparingly prior to the Lehman bankruptcy, with initial amounts outstanding of less than $\$ 40$ billion (see Figure 3). After Lehman, amounts outstanding rose sharply to a peak of almost $\$ 130$ billion in late September 2008, before tailing off gradually for the remainder of the program. ${ }^{12}$ Authorization for lending under the PDCF expired on February 1, 2010, the same date as the expiration of the TSLF.

\section{How the Facilities Worked ${ }^{13}$}

Treasury collateral made available through the TSLF was allocated via auction. The day before each auction, the Fed announced the par value of the offering amount, the

\footnotetext{
${ }^{9}$ As with the discount window, the names of borrowers are not revealed by the Fed in real time. Moreover, until after the crisis, borrower names were never revealed, even with a delay. Nonetheless, stigma is thought to exist because of a view that market participants are able to gather some information about who borrows from the Fed.

${ }^{10}$ Armantier, Krieger, and McAndrews (2008) make this point in their discussion of the Fed's Term Auction Facility, established in December 2007 to allocate funds to depository institutions via auction.

${ }^{11}$ Note that we do not consider the TSLF Options Program, through which the Fed auctioned options allowing dealers to borrow Treasury securities via the TSLF. Over the course of the program, the Fed held six auctions for options with five exercise dates. Dealers exercised options on three occasions, with a maximum amount exercised of $\$ 47.2$ billion.

${ }^{12}$ Note that we do not consider borrowing by other broker-dealers under terms similar to that of the PDCF. Fleming (2012) reports PDCF borrowing peaked at \$147 billion when including this other brokerdealer credit.

${ }^{13}$ See Fleming, Hrung, and Keane (2009) and Adrian, Burke, and McAndrews (2009) for a fuller description of these facilities.
} 
particular basket of Treasury securities it was willing to lend, and collateral eligible for delivery against the Treasury securities. "Schedule 1" collateral consisted of the collateral eligible in the Fed's open market operations, that is, Treasury securities, agency debt securities, and agency MBS. "Schedule 2" collateral consisted of Schedule 1 collateral (Fedeligible collateral) plus other investment grade debt securities. ${ }^{14}$

Auctions were typically held at 2 p.m. eastern time and were open for 30 minutes. Dealers could submit up to two bids. The minimum bid was $\$ 10$ million, each bid could be for no more than 20 percent of the offering amount, and each dealer could be awarded no more than 20 percent of the offering amount. The auctions were single-priced, so that all accepted dealer bids were awarded at the same rate, which was the lowest rate which filled the auction (also called the stop-out rate). The minimum fees for Schedule 1 and Schedule 2 auctions were 10 and 25 basis points (per annum), respectively.

Shortly after the auction close, the Fed informed dealers of their firm's awards and posted summary auction results to the New York Fed's website. Loans settled on the business day following auction. Treasury collateral was allocated to dealers on a pro rata basis, so that a dealer awarded $10 \%$ of the offering amount received a $10 \%$ share of each Treasury security offered. The Fed reserved the right to substitute lent general collateral each day so as to avoid providing collateral that might trade with scarcity value in the repo market.

To mitigate credit risk, the Fed imposed a haircut on the collateral pledged by dealers, so that dealers had to pledge collateral with a market value greater than the market value of the Treasury securities being borrowed. ${ }^{15}$ Moreover, dealers had to ensure that the market value of their collateral remained sufficient on a daily basis. Dealers might therefore need to make collateral substitutions over the term of a loan if the pledged collateral deteriorated in value or fell out of the eligible collateral pool.

\footnotetext{
${ }^{14}$ Schedule 2 collateral originally included Schedule 1 collateral plus AAA/Aaa-rated non-agency residential MBS, commercial MBS, and agency collateralized mortgage obligations (CMOs). Eligible collateral was expanded to include AAA/Aaa-rated asset-backed securities (ABS) starting with the May 8, 2008 auction, and all investment grade debt securities starting with the September 17, 2008 auctions.

${ }^{15}$ Note that the Fed did not suffer credit losses in either of these facilities and that the facilities were thus profitable for the Fed and hence U.S. taxpayers.
} 
In contrast to the TSLF, the PDCF was a standing facility, in which dealers were allocated funds at a set rate against eligible collateral. The rate was set equal to the discount window's primary credit rate, although the Fed also imposed an additional fee on frequent borrowers. ${ }^{16}$ Eligible collateral originally comprised Fed-eligible collateral plus investmentgrade corporate securities, municipal securities, MBS, and ABS, but was expanded to include all collateral eligible for tri-party repo - including non-investment grade securities and equities - after September 14, 2008. As with the TSLF, the Fed imposed a haircut on the pledged collateral to mitigate credit risk.

\section{Data}

\section{A. TSLF and PDCF Borrowings}

Our TSLF and PDCF data comes from three sources. First, certain aggregate information about program operations was released around the times of the operations. ${ }^{17}$ For the TSLF, information announced in advance of an operation included the total quantity of Treasury collateral offered and the type of collateral that could be pledged against the Treasury securities. After the operation, the Fed disclosed the aggregate quantity bid, the quantity awarded, and the stop-out rate (see appendix Table A1). For the PDCF, the Fed disclosed the average amount borrowed and borrowing outstanding on a weekly basis.

Second, on December 1, 2010, the Fed released additional information about transactions conducted to stabilize markets during the financial crisis. ${ }^{18}$ For both the TSLF and PDCF, this includes information on individual dealer borrowings through the facility, including the name of the borrower and the amount lent (par value and market value in the case of the TSLF). It also includes information on the collateral pledged, including the

\footnotetext{
${ }^{16}$ At program, inception, the frequency-based fees were assessed on borrowers who accessed the PDCF on more than 30 business days out of 120 business days. The fees were later assessed on borrowers who accessed the facility on more than 45 business days.

${ }^{17}$ This information is available on the New York Fed's website at $<\mathrm{http} / /$ www.newyorkfed.org/markets/tslf/termseclending_Historical.cfm>.

${ }^{18}$ This information is available on the Fed's website at $<$ http://www.federalreserve.gov/newsevents/reform_tslf.htm>.
} 
market value of the collateral pledged, the collateral type, and the collateral rating. The collateral information is provided as of the start date of a new loan and, in the case of the TSLF, is aggregated to reflect all of a dealer's outstanding TSLF loans as of that date.

Third, for the TSLF, we utilize a proprietary dataset with somewhat greater information than the data released December 1, 2010. In particular, while the dataset released in December 2010 includes quantities borrowed and lending fees (which are based on the stop-out rate), this additional data includes the particular fees bid and the associated quantities, regardless of whether the bid was successful or not. Such information is available for each bid in instances when dealers submitted two bids. As a result, our study goes beyond the analysis in Krishnamurthy, Nagel, and Orlov (2013) by examining ex-ante bidding behavior and not just ex post auction realizations in the TSLF.

Summary statistics across TSLF and PDCF borrowing opportunities, reported in Table II, indicate substantial variation in borrowing behavior over time. In TSLF Schedule 1 operations, for which the offering amount was always \$25 billion, bid-to-cover ratios ranged from 0 to 2.1, the number of bidding dealers ranged from 0 to 14 , and the stop-out rate ranged from the minimum fee of 10 basis points at numerous operations to 151 basis points at the post-Lehman bankruptcy (September 18, 2008) operation. In TSLF Schedule 2 operations, for which the offering amount ranged from $\$ 25$ billion to $\$ 75$ billion, bid-tocover ratios ranged from 0 to 2.0, the number of bidding dealers ranged from 0 to 16 , and the stop-out rate ranged from the minimum fee of 25 basis points at numerous operations to 322 basis points at the October 15, 2008 operation. In the PDCF, in which there was no set borrowing limit, the amount borrowed ranged from $\$ 0$ to $\$ 130$ billion, and the number of borrowing dealers ranged from 0 to 10 .

Summary statistics for individual dealer borrowing from the facilities, reported in Table III, indicate substantial variation in behavior across dealers. Citigroup borrowed in 63 of the 91 TSLF operations, and from the PDCF on 174 days, with average borrowing (across operations at which it did and did not borrow) of $\$ 2.1$ billion at TSLF Schedule 1 operations, $\$ 3.8$ billion at TSLF Schedule 2 operations, and \$3.7 billion at the PDCF. At the other 
extreme, Daiwa Securities never borrowed from the TSLF and borrowed only once from the PDCF. ${ }^{19}$

While Table III indicates high variation in borrowing behavior across dealers, it also demonstrates a certain consistency across facility types for a given dealer. That is, dealers who borrowed heavily from one facility tended to borrow heavily from another. The correlation coefficients for average amount borrowed are thus $83 \%$ between TSLF Schedules 1 and 2, 17\% between TSLF Schedule 1 and the PDCF, and 37\% between TSLF Schedule 2 and the PDCF. The most striking inconsistency in borrowing behavior across facility types is that dealers with European parents were often heavy borrowers from the TSLF, but very light borrowers from the PDCF. RBS, for example, borrowed from the TSLF on 57 occasions, but never borrowed from the PDCF.

Not only was there variation across dealers and facilities in borrowing amounts, but there is evidence of substantial variation in dealer behavior for a given operation as shown in Figure 4. The figure plots dealer bid rates for every dealer-auction pair for both TSLF Schedule 1 (Figure 4A) and Schedule 2 (Figure 4B) operations. For instances in which a dealer submitted two bids, we plot the average bid, weighted by bid amounts. ${ }^{20}$ The figure illustrates tremendous variation in dealer bid rates, especially after the failure of Lehman. For example, at the September 18, 2008 Schedule 1 auction, 10 dealers submitted bids, ranging from 10 to 351 basis points, and at the October 15, 2008 Schedule 2 operation, 11 dealers submitted bids, ranging from 60 to 1500 basis points.

\footnotetext{
${ }^{19}$ To the extent possible, our analysis incorporates the 20 firms that were primary dealers at the start of the programs, including the five firms (Bear Stearns, Countrywide, Dresdner Kleinwort, Lehman Brothers, and Merrill Lynch) that were no longer primary dealers at the end of the programs. Our analysis excludes the three firms that became primary dealers while the facilities were operating (Jefferies, RBC, and Nomura), because all three firms became primary dealers in June or July 2009 when use of the facilities was winding down as market conditions improved (and none of the three firms ever borrowed via the facilities).

${ }^{20}$ In Schedule 1 operations, dealers submitted one bid on 125 occasions and two bids on 69 occasions. In Schedule 2 operations, dealers submitted one bid on 253 occasions and two bids on 168 occasions.
} 


\section{B. Repo Rates}

Our source for repo rate data is the New York Fed's primary dealer survey. Each morning, before its typical open market operation time of 9:30, the trading desk at the New York Fed collects information from primary dealers on general collateral repo rates for Treasury securities, agency debt securities, and agency MBS. These data are used to help gauge funding market conditions and to set spreads for the Fed's open market operations. We primarily use data on one-month repo rates, which are averaged from indicative rates provided by a subset of primary dealers.

\section{Dealer Conditions}

We collect data from Bloomberg on two measures of dealer balance-sheet conditions during the crisis, cumulative equity return and leverage:

(i) Cumulative equity return measures the equity performance (return) of a firm from January 2, 2007.

(ii) Leverage is measured by the ratio of a firm's quasi-market value of assets (i.e., the market value of equity plus the book value of non-equity liabilities) to market value of equity, where the book value of non-equity liabilities is measured as the book value of assets minus the book value of equity.

While book data are available on a quarterly frequency, the market value of equity is updated on a daily basis. It follows that the quasi-leverage measure changes on a daily basis within a quarter due to market equity fluctuations, and across quarters also due to updated information on the book value of non-equity liabilities. While in tables and figures we refer to the measure as quasi-leverage, in the text we simply call it leverage for parsimony of expression. $^{21}$

\footnotetext{
${ }^{21}$ Note that the primary dealers that participated in the facilities are often subsidiaries of larger financial firms. Leverage and equity performance are measured for the holding company in such instances. In some instances, leverage and equity returns are not available at all. Cantor Fitzgerald, in particular, is not publicly traded and is thus excluded from the regression analyses.
} 
Summary statistics for the equity return and leverage variables are reported in Table IV. Given that the TSLF and PDCF were introduced and operated during the financial crisis, it is not surprising to see a mean cumulative equity return of $-51 \%$ since January 2, 2007 with a worst performance of $-99.9 \%$ and a best performance of $4.9 \%$. The mean leverage ratio is 42 and varies from a low of 5 to a high of over 680 . The high maximum leverage ratio is not surprising because the market value of equity approaches zero for a bankrupt firm. The other statistics indicate substantial variation in leverage and returns in both the cross section and the time series, as the last two columns illustrate. That is, there is substantial variation in equity returns and leverage across dealers at given points in time, as well as over time for given dealers. The cross-sectional variation is the key variation we exploit in our empirical analysis, as we control for time-series variation through time fixed effects.

\section{Money Market Fund Collateral}

Our money market fund (MMF) collateral data comes from the Securities and Exchange Commission website and is based on quarterly filings of 40 large money market funds. Each observation in the raw MMF dataset pertains to one repo between a specific fund and a specific counterparty and includes details such as purchase date, maturity date, collateral class, face value, maturity amount, and collateral value. There are nine collateral classes, including Treasuries, agencies, corporate debt, commercial paper, municipals, foreign debt, equities, structured finance, and mixed pool. The information is thus detailed enough to allow us to distinguish collateral that is Fed eligible from that which is not. Table IV reports summary statistics across dealers for the share of pledged collateral that was nonFed eligible over the November 1, 2007 to February 29, 2008 period, showing that the share ranged from $0 \%$ to $61 \%$, and averaged just under $20 \% .{ }^{22}$

\footnotetext{
${ }^{22}$ Note that we have no collateral data over this period for five of the 20 firms that were primary dealers in March 2008, including Cantor Fitzgerald, Countrywide, Dresdner Kleinwort, Daiwa, and RBS.
} 


\section{Results}

We explain dealer behavior in each of the facilities with our measures of dealer financial conditions. Let $y_{i t}$ be a measure of behavior of dealer $i$ on TSLF auction date $t$ or PDCF borrowing date $t$ and let $x_{i t-1}$ be a measure of dealer $i$ 's financial condition as of the day preceding the facility operation date. Our basic regression specification is then:

$$
y_{i t}=\alpha_{0}+\gamma_{t}+\beta x_{i t-1}+\varepsilon_{i t}
$$

where $\gamma_{t}$ represents a time fixed effect to control for any pure time-series variation that affects $y_{i t}$. Dealer behavior is estimated separately for the TSLF Schedules 1 and 2 and PDCF because of the different designs of the facilities and/or differing collateral that could be pledged.

As proxies for dealer behavior $y_{i t}$, we use the dealer's bidding or borrowing (i.e., participation) decision, the bid or borrowing amount, and the TSLF bid rate. Our proxy for financial conditions is the dealer's cumulative equity return from January 2, 2007 or the dealer's leverage. ${ }^{23}$ Because of the high correlation between the two variables, we generally estimate (1) using equity return or leverage separately. However, for completeness, we also estimate a version of (1) with both return and leverage:

$$
y_{i t}=\alpha_{0}+\gamma_{t}+\beta_{1} \text { Equity return }_{i t-1}+\beta_{2}\left(10 / \text { Leverage }_{i t-1}\right)+\varepsilon_{i t}
$$

\section{A. Participation}

We first relate a dealer's decision to participate in a facility to its financial condition. Participation is defined by an indicator variable equal to one if a dealer submitted a bid in a TSLF auction or borrowed at the PDCF, and zero otherwise. Results from least squares regressions, reported in Table $\mathrm{V}$, support the hypothesis that firms with weaker financial

\footnotetext{
${ }^{23}$ Note that in our specifications, we actually use the reciprocal of leverage (multiplied by 10 for presenting the results) as our independent variable given that leverage has a long right tail. To the extent that lower equity returns or higher leverage impact LOLR utilization in the same manner, the coefficients for equity returns and 10/leverage will be of the same sign.
} 
conditions were more likely to participate ${ }^{24}$ Equity return is negative and statistically significant in the TSLF Schedule 1 and Schedule 2 operations (columns 1 and 4) and the PDCF (column 7). The reciprocal of leverage is negative and statistically significant in both Schedule 1 and Schedule 2 operations (columns 2 and 5), and negative and statistically insignificant in the PDCF (column 8). Individual coefficients are generally weaker when we include both equity return and leverage in the regressions, but the coefficients are jointly significant at the $10 \%$ level or better for all facilities. ${ }^{25}$

The effect of dealer financial conditions on participation is not only statistically significant but economically significant. Using the coefficients in columns 1, 4, and 7 of Table V, we find that a one standard deviation negative shock to the cumulative equity return (i.e., -26\%) increases a dealer's likelihood of participation in TSLF Schedule 1 operations by 12 percentage points (pp) (where the average participation rate is 34\%), in TSLF Schedule 2 operations by $20 \mathrm{pp}$ (where the average participation rate is 43\%), and in the PDCF by $7 \mathrm{pp}$ (where the average participation rate is $12 \%$ ). The analogous increases in participation for a one standard deviation negative shock to the reciprocal of leverage are $12 \mathrm{pp}, 15 \mathrm{pp}$, and 2 $\mathrm{pp}$, respectively.

The baseline specifications we present fully control for aggregate variation in funding market conditions through time fixed effects. However, to better understand the factors driving aggregate participation over time, we also test specifications in which we drop the time fixed effects, but include the one-month agency MBS repo spread (defined as the onemonth agency MBS repo rate minus the one-month Treasury repo rate) and the crosssectional mean values of dealer financial conditions (measured across all dealers and not just the participating ones) as of the day preceding a given operation:

$$
y_{i t}=\alpha_{0}+\alpha_{1} \text { Repo Spread }_{t}+\beta_{1} \text { Equity return }_{i t-1}+\beta_{2} \overline{\text { Equlty return }}_{t-1}+\varepsilon_{i t}
$$

and

\footnotetext{
${ }^{24}$ We report results using least squares because the coefficients are easier to interpret. Results in appendix Table A2 show that the results are, if anything, somewhat stronger if we instead use probit estimation, which accounts for the binary nature of the dependent variable.

${ }^{25}$ In the case of the PDCF, both variables are significant (column 9), but the leverage coefficient has the incorrect sign.
} 


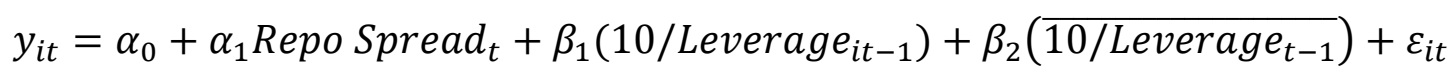

As shown in Table VI, the mean equity return coefficient is positive and statistically significant for both schedules of the TSLF, and insignificantly negative for the PDCF. The mean leverage coefficient is positive for both schedules of the TSLF and negative for the PDCF, but only statistically significant for TSLF Schedule 1 . We interpret the results as evidence of strategic interaction in the case of the TSLF, where the quantity of Treasury collateral offered is limited, so that as the financial conditions of their competitors deteriorates, dealers anticipate that competitors will bid more aggressively for liquidity and thus become less likely to participate themselves. That is, stronger dealers are "crowded out. ${ }^{, 26}$ Such crowding out is not present in the PDCF where lendable amounts are not fixed. Table VI also shows that the repo spread is positively and significantly related to participation in every specification, indicating that dealers are more likely to participate when their opportunity cost of funding in the private market is higher.

\section{B. Bid/Borrowing Amount}

We proceed to examine how the quantity bid or borrowed by a dealer varies with its financial condition. We standardize TSLF bidding amounts by defining the quantity bid as the amount of a dealer's bid (across both bids if it submitted two) divided by the maximum possible auction award. Technically, each of a dealer's two bids could be as large as the maximum auction award, so that the ratio could conceivably be as large as two. ${ }^{27}$ Empirically, the ratio rarely exceeded one. We cap the ratio at one, so that our dependent

\footnotetext{
${ }^{26}$ Put another way, stronger dealers seem to have better financing opportunities elsewhere (i.e., in the private market) and thus choose to participate less in the TSLF given the presence of weaker dealers that have fewer and/or more expensive financing opportunities elsewhere. Note that the relative lack of participation of stronger firms does not mean that such firms did not benefit from the facility if participation of weaker firms eased funding conditions and reduced the chances of fire sales more generally. Also note that the TSLF imposed a 20\% award limit at each auction, ensuring that liquidity could be supplied to at least five dealers.

${ }^{27}$ If an auction were oversubscribed, then awards would be rationed at the stop-out rate. It follows that a dealer submitting two bids might want to increase the size of its less competitive bid to increase its award should the auction stop at the lower rate.
} 
variable ranges between zero and one. The PDCF did not have explicit borrowing limits; PDCF borrowing amounts are in tens of billions of dollars.

We again test three model specifications for each of the operation types. These specifications are conditional on a dealer bidding in a TSLF auction or borrowing at the PDCF, which effectively drops all observations for which the dependent variable equals zero. While the earlier results showed that dealer participation was related to its financial condition, the results conditional on participation address whether financial conditions can further explain the quantity borrowed or bid if a bid is submitted.

Results of our least squares regressions, reported in Table VII, provide evidence that firms with weaker financial conditions tended to bid or borrow larger quantities. ${ }^{28}$ The equity return variable is negative and statistically significant for both TSLF Schedule 2 operations and PDCF borrowings (columns 4 and 7), and negative but insignificant for TSLF Schedule 1 operations (column 1). The reciprocal of the leverage variable is negative and statistically significant for PDCF borrowings (column 8), but negative and insignificant for the TSLF operations (columns 2 and 5). The results are robust to including equity return and leverage together in the specifications (columns 3,6, and 9).

As with participation, the effect of dealer financial conditions is not only statistically significant but economically significant. Using the coefficients in columns 4 and 7 of Table VII, we find that a one standard deviation negative shock to the cumulative equity return increases a dealer's borrowing ratio in the Schedule 2 TSLF by 12 pp (where the average ratio conditional on participation is $46 \%$ ), and PDCF borrowing amounts by $\$ 5$ billion (where the average borrowing amount conditional on borrowing is $\$ 7$ billion). The analogous increases in borrowing for a one standard deviation negative shock to the reciprocal of leverage are $6 \mathrm{pp}$ and $\$ 6$ billion, respectively.

\footnotetext{
${ }^{28}$ Results in appendix Table A3 show that the results are, if anything, somewhat stronger if we instead use Tobit estimation for the TSLF specifications to account for the fact that the dependent variables are censored at one.
} 


\section{Bid Rate}

Our third measure of liquidity demand is a dealer's bid rate. This variable is defined as the average bid rate in TSLF auctions, weighted by bid amount for instances in which a dealer submitted two bids. Bid rates are naturally not observed for dealers that did not submit bids, so the sample is necessarily conditional on a dealer having submitted a bid. The bid rate analysis is only pertinent to the TSLF because the PDCF was a standing facility with a fixed borrowing rate for a given day.

The results of our least squares regressions, reported in Table VIII, are supportive of the hypothesis that firms with weaker financial conditions bid higher rates. ${ }^{29}$ Equity return is negative and statistically significant for Schedule 2 operations (column 4), and negative but insignificant for Schedule 1 operations (column 1). The reciprocal leverage variable is negative and statistically significant for both schedules (columns 2 and 5). Some individual coefficients become insignificant when both return and leverage are included together (columns 3 and 6 ), but the two variables are jointly significant at the $5 \%$ level for both schedule types.

As with participation and bid amounts, the effects of dealer financial conditions are not only statistically significant but economically significant. Using the coefficients in columns 1 and 4 of Table VIII, we find that a one standard deviation negative shock to the cumulative equity return increases a dealer's bid rate in Schedule 1 auctions by 3 basis points (where the average bid rate is 29 basis points) and 57 basis points in Schedule 2 auctions, (where the average bid rate is 94 basis points). The analogous increases in bid rates for a one standard deviation negative shock to the reciprocal of leverage are 11 and 38 basis points, respectively.

\footnotetext{
${ }^{29}$ Results in appendix Table A4 show that the results are somewhat stronger if we instead use Tobit estimation for the specifications to account for the fact that the dependent variables are censored at the minimum bid rates (of 10 and 25 basis points, respectively, for Schedule 1 and Schedule 2 operations).
} 


\section{Additional Analyses}

While both the TSLF and PDCF offered secured loans to primary dealers, there were important differences in the design of these facilities (see Table I). The TSLF offered 28-day term loans at periodically scheduled auctions, whereas the PDCF offered overnight loans on an as-needed basis. The TSLF allocated collateral via auction at an auction-determined rate, whereas the PDCF lent funds on a standing basis at a predetermined rate. Moreover, there was a broader range of eligible collateral accepted in the PDCF (e.g., equity and whole loans after September 14, 2008) than the TSLF. In this section, we exploit these cross-sectional differences in program terms to better understand dealer behavior in the facilities.

\section{A. Collateral Effects}

One of the most important distinctions among the facilities was the varying types of assets that could be pledged as collateral. The ability of firms to pledge a wider range of collateral at the PDCF than in the TSLF, and in TSLF Schedule 2 operations versus Schedule 1 operations, may have provided incentive for some firms to prefer borrowing at one facility over another. In particular, the ability to pledge corporate and municipal bonds at the PDCF in the pre-Lehman period and equity and whole loans in the post-Lehman period may have been valuable to firms with large amounts of these securities on their balance sheets.

Table IX shows the average proportion of collateral pledged by asset type in the TSLF (Schedule 2) and PDCF. ${ }^{30}$ Panels A and B show that the quality and type of collateral posted at TSLF Schedule 2 operations varied considerably across dealers. Panel A shows that some dealers only posted collateral with a composite rating of Aaa/AAA, whereas only about half of the pledged collateral of other dealers (for example, Barclays Capital and Credit

\footnotetext{
${ }^{30}$ Collateral information provided by the Fed lists the market value of collateral as of the start of any borrowing and mixes the TSLF Schedule 1 and Schedule 2 collateral together. We infer the collateral pledged against a particular Schedule 2 borrowing by backing out the higher quality collateral pledged against Schedule 1 borrowings as well as the borrowings for any earlier but outstanding Schedule 2 borrowings. Collateral could be changed over the term of a loan, so our TSLF numbers should be considered estimates of collateral pledged at the start of a borrowing. In contrast, the PDCF numbers are not estimates because such data is provided separately from TSLF data and because the frequency of PDCF borrowings matched the borrowing term.
} 
Suisse), was rated Aaa/AAA. ${ }^{31}$ In Panel B of Table IX, we see that heavy borrower Citigroup posted a relatively high share (63\%) of agency-backed mortgage securities as collateral. Other heavy program borrowers, such as Deutsche Bank, posted relatively less agencybacked mortgage securities as collateral (8\%), but more non-agency backed mortgage securities (54\%) and other securities. Barclays posted high shares of both ABS (30\%) and corporate securities $(41 \%)$.

We find that eight dealers pledged substantial proportions of equity in the PDCF, ranging between $9 \%$ for Lehman Brothers and almost $60 \%$ for Credit Suisse (see Panel C of Table IX). ${ }^{32}$ Firms that pledged greater shares of equity tended to be heavy borrowers at the PDCF. Indeed, the correlation between average amount borrowed at the PDCF and the proportion of equity pledged as collateral is 0.39 , suggesting that the ability to pledge equity was a strong motive for dealers to borrow at the PDCF. Moreover, dealers that pledged large proportions of equity at the PDCF also pledged large proportions of other risky assets such as MBS/CMOs, ABS, corporate securities and municipal securities at both the PDCF and TSLF (see Panels B and D of Table IX), and borrowed extensively at TSLF Schedule 2 operations. Consistent with this notion, the correlation between the average amount borrowed at TSLF Schedule 2 and the proportion of equity pledged as collateral at the PDCF is 0.36 . The distribution of collateral pledged at the facilities reinforces the notion that firms with risky assets on their balance sheets had a greater need for funds during the crisis and pledged these assets to borrow substantively at both facilities.

We proceed to formally test the idea that the proportion of illiquid collateral on dealers' balance sheets was a determinant of their demand for liquidity at the PDCF and TSLF Schedule 2 operations (we omit TSLF Schedule 1 auctions since only liquid Fedeligible collateral was accepted in that program). We do this by relating dealers' bidding/borrowing decision to the quantity of non-Fed-eligible collateral pledged by dealers.

\footnotetext{
${ }^{31}$ Until the September 17, 2008 operation, Schedule 2 borrowings were only against Aaa/AAA collateral. It follows that any dealer who borrowed before that time must have only pledged Aaa/AAA collateral over the period and that any dealer that did not borrow after the collateral schedule was broadened on September 17 must have never pledged lower quality collateral.

32 Eligible collateral was expanded to include equities after September 14, 2008. It follows that any dealer who borrowed before that time did not pledge equities over the period.
} 
The hypothesis is that dealers with greater shares of less liquid collateral would tend to bid for larger quantities of funds at the facilities.

Let Non-Fed eligible $e_{i, p r e-f a c}$ be dealer i's share of collateral pledged to money market funds that is not Fed eligible over the November 1, 2007 to February 29, 2008 period, as reported in Table IV. This variable is intended to gauge the collateral on dealers' balance sheets before the facilities were introduced in March 2008. We modify equation (1) by including this additional variable to explain dealer behavior, so we have:

$$
y_{i t}=\alpha_{0}+\gamma_{t}+\beta x_{i t-1}+\delta \text { Non }- \text { Fed Eligible } e_{i, p r e-f a c}+\varepsilon_{i t}
$$

We also test specifications in which we allow interaction effects between our financial condition variables and our collateral variables, to test whether worse performing dealers are more likely to demand liquidity when they have greater shares of less liquid collateral:

$y_{i t}=\alpha_{0}+\gamma_{t}+\beta x_{i t-1}+\delta$ Non - Fed Eligible $e_{i, p r e-f a c}+\theta x_{i t-1} *$ Non - Fed Eligible $e_{i, p r e-f a c}+\varepsilon_{i t}$

The results in Table $\mathrm{X}$ show that the non-Fed-eligible collateral coefficient is positive and statistically significant for both the TSLF Schedule 2 (columns 1 and 3) and PDCF (columns 5 and 7). ${ }^{33}$ The collateral coefficients are of similar magnitude in specifications including either equity return or leverage, and the coefficients on equity return and leverage generally remain significant. ${ }^{34}$ The results suggest that dealers with less liquid collateral on their balance sheet before the crisis tended to borrow more from the facilities.

As with our other measures of dealer conditions, the effect of non-Fed-eligible collateral is not only statistically significant but economically significant. Using the coefficients in columns 1 and 5 of Table $\mathrm{X}$, we find that a one standard deviation positive shock to non-Fed-eligible collateral before the crisis (that is, an increase of $17 \mathrm{pp}$ ) increases a

\footnotetext{
${ }^{33}$ We also report results in appendix Table A5 based on a variable defined as each dealer's share of collateral pledged to money market funds that was non-Fed eligible over the three-month period preceding an operation. Such results are similar to, but somewhat weaker than, the results using the share pledged to money market funds for the fixed three-month period before the facilities were introduced.

${ }^{34}$ For parsimony, we estimate the models on unconditional bid/borrowing amounts and not participation and conditional bid/borrowing amounts separately. For comparison, results for unconditional borrowing amounts excluding the collateral variables are reported in appendix Table A6.
} 
dealer's borrowing ratio in the Schedule 2 TSLF by $6 \mathrm{pp}$ (where the average ratio unconditional on participation is $20 \%$ ), and PDCF borrowing amounts by $\$ 0.7$ billion (where the average unconditional borrowing amount is $\$ 0.9$ billion).

The results in Table $\mathrm{X}$ also show that the interaction terms between the collateral share variable and equity return are negative and significant for the PDCF (columns 6 and 8), but of mixed sign and insignificant for the TSLF (columns 2 and 4). The negative and significant coefficients for the PDCF imply that it is the combination of low equity returns and illiquid collateral that spurs dealers to borrow larger amounts, rather than either variable alone. Indeed, the equity return and quasi leverage variables lose individual significance when the interaction terms are included.

\section{B. Short-Term vs. Long-Term Borrowing}

Aside from collateral, borrowing term was another key distinction between the TSLF and PDCF. TSLF loans were for 28 days, whereas PDCF loans were overnight. Aside from differences in collateral (discussed in the preceding section) and borrowing fees (discussed in the next section), the time a dealer expected to need financing was likely a consideration in choosing which facility to borrow from. That is, even if the PDCF borrowing rate exceeded the implied TSLF borrowing rate, it may still have been cheaper for dealers with short-term funding needs to borrow from the PDCF instead of the TSLF. By rolling over their PDCF funding, firms could borrow for the number of days that they needed funds rather than commit to paying the fee for 28 days in the TSLF. The Fed did charge an additional fee to frequent PDCF borrowers (independent of the amount borrowed), which may have constrained such rollover funding. ${ }^{35}$

In Table XI, we provide descriptive statistics on the extent of rollover funding of PDCF borrowers. We define a borrowing spell as the period of time over which a dealer's outstanding borrowing amount was positive. We find that 9 of 18 PDCF borrowers had a mean spell length of at least 24 operation days. More striking than the mean, however, is the

\footnotetext{
${ }^{35}$ We do not have information on the magnitude of the fees and are thus unable to determine the extent to which such fees may have affected dealer behavior.
} 
maximum, especially in comparison to the total number of borrowing days. For the 18 firms that borrowed from the PDCF, an average of $85 \%$ of all of their borrowing days came from a single spell (the ratio is $83 \%$ if we limit the sample to dealers who borrowed at least 10 times). It appears that heavy users of the PDCF rolled over funding frequently, despite any additional fees they might have had to pay. ${ }^{36}$

These borrowing patterns are illustrated in Figure 5 for Citigroup, a heavy user of the PDCF. Citigroup rolled over its PDCF borrowing frequently at a time when it also borrowed extensively from the TSLF. In fact, $87 \%$ of Citigroup's PDCF borrowing days are accounted for by a single spell of 152 operation days starting September 15, 2008. The evidence suggests that dealers borrowed from the PDCF not because they valued the flexibility of shorter-term borrowing, but because they needed funds in addition to what they could obtain from the TSLF.

\section{Cost of Borrowing and Stigma}

The cost of borrowing across facilities sheds light on dealer preferences across the facilities, as well as between the facilities and the private market. Given that the PDCF was uniformly more flexible than the TSLF, one might expect that the auction-determined TSLF borrowing costs would have been uniformly lower than the cost of borrowing from the PDCF. Given that the only meaningful difference between TSLF Schedule 2 and Schedule 1 operations was the broader collateral eligibility in Schedule 2 operations, one would expect Schedule 1 costs to have been lower than Schedule 2. Lastly, since agency MBS collateral was the least liquid collateral accepted at Schedule 1 operations, one might expect the implied TSLF Schedule 1 borrowing cost to have equaled the agency MBS repo rate.

\footnotetext{
${ }^{36}$ It follows that participation in a facility is highly effective at predicting future participation, especially for the PDCF. Appendix Table A7 reports results of participation regressions where participation over the preceding 20 business days is included as an independent variable. The inclusion of this variable eliminates statistical significance of the equity return coefficient for the PDCF, but the equity return and leverage coefficients remain significant (albeit smaller in magnitude) for the TSLF. The importance of prior participation may be explained by stigma (whereby a dealer is reluctant to participate if it has not previously, but is less hesitant if it has previously), although other persistent firm-specific attributes may also explain the pattern. We explore stigma in greater detail in the next section.
} 
Facility borrowing costs and the one-month agency MBS repo rate are plotted in Figure 6. Results are broadly consistent with the relationships hypothesized above. That is, PDCF borrowing rates did in fact largely exceed implied TSLF Schedule 1 and Schedule 2 borrowing rates. ${ }^{37}$ Moreover, TSLF Schedule 2 rates were uniformly above Schedule 1 rates. Lastly, TSLF Schedule 1 rates tended to track agency MBS repo rates quite closely.

However, the expected relationships did not hold for the period after Lehman's failure. From October 2008 to January 2009, the agency MBS repo rate exceeded the implied TSLF Schedule 1 borrowing rate. That is, dealers were apparently willing to pay more to borrow in the private market than to borrow from the TSLF. The anomalous rate relationship may be explained by stigma, despite the TSLF's auction design, as suggested by Krishnamurthy, Nagel, and Orlov (2013). However, heightened transaction costs of financing the borrowed Treasury collateral in the private market at the time may have also been a factor. $^{38}$

In September and October 2008, the implied TSLF Schedule 2 borrowing rate exceeded the PDCF rate. Such a relationship does not suggest a stigma from borrowing from the Fed per se, but rather a stigma from borrowing from a standing facility as opposed to an auction facility. In fact, Armantier, Ghysels, Sarkar, and Shrader (2011) uncover just such a relationship in their comparison of analogous facilities set up for depository institutions: the Term Auction Facility and the discount window.

\section{Dealer Financial Performance and Repo Exposure}

While the funding difficulties faced by dealers reflected the performance and liquidity of their assets, it may have also reflected the structure of their liabilities. While data limitations preclude an extensive analysis of this issue, we do examine, for a subset of dealers, the relationship between the financial condition measures we employ and the repo liabilities ratio, which is the ratio of the sum of securities sold to repurchase and fed funds

\footnotetext{
${ }^{37}$ Implied TSLF borrowing rates are estimated as the TSLF stop-out rates plus the rate at the time on onemonth Treasury general collateral repos.

${ }^{38}$ It is also possible that the reported agency MBS repo rate at the time was not representative due to illiquidity in the term repo market.
} 
borrowings to total liabilities. ${ }^{39} \mathrm{We}$ obtain data from the quarterly reporting of dealer balance sheets as recorded in SNL Financial. We focus on the period from early 2007 until the failure of Bear Stearns (as the extent of repo liabilities post-Bear Stearns would be affected by the TSLF and the PDCF). Finally, we exclude foreign firms from this analysis due to differing accounting standards.

Figure 7A and 7B show the relationship between the repo liabilities ratio and the two measures of financial conditions we employ in our analysis, cumulative equity return and the reciprocal of quasi-leverage, respectively. There appears to be a strong relationship. Weaker U.S. dealers (Countrywide, Bear Stearns, Merrill Lynch and Lehman Brothers) had higher repo liabilities ratios (25\%-35\% range), whereas stronger U.S. dealers (Goldman Sachs, Citigroup, J.P. Morgan and Bank of America) had lower repo liabilities ratios (10\%-17.5\% range). While more work is needed to understand the full determinants of dealer financial performance, Figures 7A-7B suggest that reliance on short-term wholesale funding in repo markets was a contributor, explaining both why the Fed created the TSLF and PDCF, and why the weaker dealers borrowed more from these facilities.

\section{Conclusion}

Do central bank lender-of-last-resort facilities elicit greater and more aggressive participation from less capitalized financial firms? We answer this question by examining financial conditions of dealers that participated in the Federal Reserve's Term Securities Lending Facility and Primary Dealer Credit Facility, LOLR facilities that provided liquidity against a range of assets as collateral during 2008-09. We find that, in the cross-section, dealers with more leverage and more negative returns prior to borrowing from the facilities were more likely to participate in the programs, borrow more, and - in the case of the TSLF - at higher bidding rates. Moreover, dealers with less liquid collateral on their balance sheets before the facilities were introduced also tended to borrow more. Further, interaction effects between financial performance and balance-sheet liquidity seem to have been especially

\footnotetext{
${ }^{39}$ While there are other forms of short-term debt that dealers rely on, such as commercial paper, we do not have reliable publicly available data on these other types.
} 
important in explaining dealer behavior. Finally, the effect of a decrease in the health of a dealer is to depress participation by other dealers (in TSLF auctions), suggesting that weaker dealers "crowded out" stronger dealers (who presumably had more attractive financing options elsewhere).

Our results demonstrate important composition effects in behavior by financial firms when central banks lend against illiquid collateral. These effects are consistent with the important trade-offs that central banks face in their lender-of-last-resort role. In particular, the results are consistent with the incentive-based argument for Bagehot (1873)'s recommendation that central banks only lend against high quality collateral. While Bagehot's original concern was primarily with the growth of the central bank's balance sheet, Bagehot's recommendation may be pertinent in the modern context when such growth is somewhat of a lesser concern, and the primary concern, as with recent financial crises, is the delay in private recapitalization or adequate de-leveraging and de-risking by financial firms.

Central banks do attempt to limit participation in their facilities to financial firms based on prior financial health and also monitor participants on an on-going basis. Central banks also impose higher haircuts for more illiquid collateral. However, such haircuts are typically not greater for weaker borrowers. Further, in a crisis situation, financial conditions change rapidly and regulators face the difficult challenge of knowing which signals to rely on. Our results suggest that through the crisis, market-based signals of dealer financial conditions continued to provide useful predictive information on dealer participation in Fed facilities, and thus indirectly, on the need to fund lower-quality, illiquid collateral. 


\section{References}

Acharya, V.V. and B. Tuckman, 2013, Unintended Consequences of Lender of Last Resort Facilities: The Case of Illiquid Leverage, Working Paper, NYU Stern School of Business.

Acharya, V.V. and D. Backus, 2009, Private Lessons for Public Banking: The Case for Conditionality in LOLR Facilities, Chapter 14, Acharya, V.V. and M. Richardson, eds, Restoring Financial Stability: How to Repair a Failed System, John Wiley \& Sons, March 2009.

Adrian, T., Burke, C. R. and J. J. McAndrews, 2009, The Federal Reserve's Primary Dealer Credit Facility, Federal Reserve Bank of New York Current Issues in Economics and Finance, 15, 4.

Adrian, T., Kimbrough, K. and D. Marchioni, 2011, The Federal Reserve's Commercial Paper Funding Facility, Federal Reserve Bank of New York Economic Policy Review, 17, 1, 25-39.

Armantier, O., Ghysels, E., Sarkar, A. and J. Shrader, 2011, Stigma in Financial Markets: Evidence from Liquidity Auctions and Discount Window Borrowing during the Crisis, Federal Reserve Bank of New York Staff Reports, 483.

Armantier, O., Krieger, S., and J. McAndrews, 2008, The Federal Reserve's Term Auction Facility, Current Issues in Economics and Finance 14, 5.

Ashcraft, A., Garleanu, N. and L.H. Pedersen, 2011, Two Monetary Tools: Interest Rates and Haircuts, NBER Macroeconomic Annual 2010, 25, 143-180.

Bagehot, W., 1873, Lombard Street, A Description of the Money Market, Richard D. Irwin Inc.

Caballero, R.J., Hoshi, T., and A.K. Kashyap, 2008, Zombie Lending and Depressed Restructuring in Japan, American Economic Review 98 (5), 1943 - 1977.

Campbell, S., Covitz, D., Nelson, W., and K. Pence, 2011, Securitization Markets and Central Banking: an Evaluation of the Term Asset-Backed Securities Loan Facility, Journal of Monetary Economics, 58, 518-531.

Coffey, N., Hrung, W., and A. Sarkar, 2009, Capital Constraints, Counterparty Risk, and Deviations from Covered Interest Rate Parity, Working Paper. Available at: http://papers.ssrn.com/sol3/papers.cfm?abstract_id=1473377.

Copeland, A., Martin, A., and M. Walker, 2010, The Tri-party Repo Market before the 2010 Reforms, Federal Reserve Bank of New York Staff Reports, 477. 
Copeland, A., Martin, A., and M. Walker, 2012, Repo Runs: Evidence from the Tri-party Repo Market, Federal Reserve Bank of New York Staff Reports, 504.

Diamond, D. and R. G. Rajan, 2005, Liquidity Shortages and Banking Crises, Journal of Finance, 60, 2, 615-647.

Duygan-Bump, B., Parkinson, P., Rosengren, E., Suarez, G.A., and P. Willen, 2013, How Effective Were the Federal Reserve Emergency Liquidity Facilities? Evidence from the Asset-backed Commercial Paper Money Market Mutual Fund Liquidity Facility, Journal of Finance, 68, 715-737.

Ennis, H. and J. Weinberg, 2013, Over-the-Counter Loans, Adverse Selection, and Stigma in the Interbank Market, Review of Economic Dynamics 16, 4, 601-616.

Flannery, M.J., 1996, Financial Crises, Payment System Problems, and Discount Window Lending, Journal of Money, Credit and Banking 28, 4, 804-24.

Fleming, M.J., Hrung, W.B., and F.M. Keane, 2009, The Term Securities Lending Facility: Origin, Design, and Effects, Federal Reserve Bank of New York Current Issues in Economics and Finance, 15, 2.

Fleming, M.J., Hrung, W.B. and F.M. Keane, 2010, Repo Market Effects of the Term Securities Lending Facility: Origin, Design, and Effects, American Economic Review: Papers \& Proceedings, 100.

Fleming, M.J., 2012, Federal Reserve Liquidity Provision during the Financial Crisis of 2007-2009, Annual Review of Financial Economics, 4, 161-177.

Gorton, G. and A. Metrick, 2012, Securitized Banking and the Run on Repo, Journal of Financial Economics, 104, 425-451.

Haldane, A. G., 2012, The Dog and the Frisbee, Speech given at the Federal Reserve Bank of Kansas City's $36^{\text {th }}$ economic policy symposium, Jackson Hole, Wyoming.

Hrung, W. and A. Sarkar, 2012, The US Dollar Funding Premium of Global Banks, Working Paper. Available at: http://ssrn.com/abstract=2117554.

Krishnamurthy, A., Nagel, S. and D. Orlov, 2013, Sizing up Repo, Journal of Finance, forthcoming.

McAndrews, J., Sarkar, A. and Z. Wang, 2008, The Effect of the Term Auctions Facility on the London Inter-Banked Offer Rate, Federal Reserve Bank of New York Staff Reports, 335.

Philippon, T. and V. Skreta, 2012, Optimal Interventions in Markets with Adverse Selection, American Economic Review 102, 1, 1-28. 
Rochet, J. and X. Vives, 2010, Coordination failures and the Lender of Last Resort: Was Bagehot Right After All? Journal of the European Economic Association 2, 6, 1116 1147.

Rose, A.K. and M.M. Spiegel, 2012, Dollar Illiquidity and Central Bank Swap Arrangements during the Global Financial Crisis, Journal of International Economics 88, 2, 326340 .

Sufi, A., 2009, Bank Lines of Credit in Corporate Finance: An Empirical Analysis, Review of Financial Studies, 22, 1057-1088.

Wu, T., 2011, The U.S. Money Market and the Term Auction Facility in the Financial Crisis of 2007-2009, Review of Economics and Statistics, 93, 617-631. 


\section{Table I. TSLF and PDCF Characteristics}

TSLF

Opening (first operation) date

Closing date

What the program did

Interest rate

Loan term

Eligible borrowers

Eligible collateral

Operation Frequency
March 27, 2008

February 1, 2010

Offered Treasury general collateral against eligible collateral

Set by auction, with minimum fee

28 days

Primary dealers

Investment grade debt securities (for Schedule 2

operations after September 14, 2008)

Periodic
PDCF

March 17, 2008

February 1, 2010

Offered funds against eligible collateral

Discount window primary credit rate

Overnight

Primary dealers

All collateral eligible for triparty repo (after September 14

2008)

Daily

Notes: The table summarizes the key terms of the Term Securities Lending Facility (TSLF) and the Primary Dealer Credit Facility (PDCF). Eligible collateral for the TSLF varied between Schedule 1 and Schedule 2 auctions. For Schedule 1, eligible collateral comprised securities eligible in the Fed's open market operations (i.e.,

Treasury securities, agency securities, and agency mortgage-backed securities). Schedule 2 collateral originally comprised Schedule 1 collateral plus AAA/Aaa-rated nonagency residential MBS, commercial MBS, and agency collaterized mortgage obligations (CMOs). Schedule 2 collateral was expanded to include AAA/Aaa-rated assetbacked securities beginning with the May 8, 2008 auction and all investment-grade debt securities beginning with the September 17, 2008 auction. Eligible collateral for the PDCF originally comprised Fed-eligible collateral plus investment-grade corporate securities, municipal securities, mortage-backed securities, and asset-backed securities. PDCF eligible collateral was expanded to include all collateral eligible for triparty repo - including non-investment grade securities and equities - after September 14, 2008. TSLF Schedule 1 auctions were held every two weeks beginning April 3, 2008 and ending June 25, 2009. TSLF Schedule 2 auctions were held every two weeks from March 27, 2008 through September 11, 2008, then weekly through April 22, 2009, then every two weeks again through July 16, 2009, then every four weeks through December 3, 2009, with a final auction five weeks later on January 7, 2010. The PDCF was open daily from March 17, 2008 to February 1, 2010. 


\section{Table II. Operation Summary Statistics}

Panel A: TSLF Schedule 1

Amount offered (billions of dollars)

Amount submitted (billions of dollars)

Amount accepted (billions of dollars)

Stop-out rate (basis points)

Bid-to-cover ratio

Number of bidding dealers

Number of awarded dealers

$\begin{array}{rrr}\text { Mean } & & \text { Standard Deviation } \\ 25.0 & 0.0 \\ 21.2 & 17.6 \\ 15.3 & 10.3 \\ 17.1 & 25.4 \\ 0.8 & 0.7 \\ 5.9 & 4.6 \\ 4.7 & 3.3\end{array}$

\begin{tabular}{rrr} 
Minimum & & \multicolumn{2}{c}{ Maximum } \\
25.0 & 25.0 \\
0.0 & 51.7 \\
0.0 & 25.0 \\
10.0 & 151.0 \\
0.0 & 2.1 \\
0.0 & 14.0 \\
0.0 & 12.0
\end{tabular}

Panel B: TSLF Schedule 2

$\begin{array}{rrr}\text { Mean } & & \text { Standard Deviation } \\ & & \\ 28.9 & 16.9 \\ 24.8 & 21.5 \\ 48.0 & 16.1 \\ 0.7 & 70.7 \\ 7.3 & 0.5 \\ 6.7 & 4.5 \\ & & 4.1\end{array}$

Minimum

Maximum

Amount offered (billions of dollars)

Amount submitted (billions of dollars)

Amount accepted (billions of dollars)

Stop-out rate (basis points)

Bid-to-cover ratio

Number of bidding dealers

Number of awarded dealers

Mean

Standard Deviation

24.7
2.6

Minimum

Maximum

Panel C: PDCF

\begin{tabular}{rr} 
Mean & \\
\hline & 15.7 \\
& 2.2
\end{tabular}

24.7

Number of awarded dealers

Notes: The table reports summary statistics for the 33 TSLF Schedule 1 auctions, 58 TSLF Schedule 2 auctions, and 470 days the PDCF was open. The stop-out rate represents the lowest rate at which bids are accepted. The bid-to-cover ratio represents the ratio of the amount submitted to the amount offered. Operation summary statistics are not conditional on dealers having participated in an operation. 


\section{Table III. Dealer Borrowing Summary Statistics}

\begin{tabular}{|c|c|c|c|c|c|c|}
\hline \multirow[b]{2}{*}{ Dealer } & \multicolumn{2}{|c|}{ TSLF Schedule 1} & \multicolumn{2}{|c|}{ TSLF Schedule 2} & \multicolumn{2}{|c|}{ PDCF } \\
\hline & $\begin{array}{c}\text { Average Amount } \\
\text { Borrowed } \\
\text { (Millions of Dollars) }\end{array}$ & $\begin{array}{l}\text { Number of } \\
\text { Borrowings }\end{array}$ & $\begin{array}{c}\text { Average Amount } \\
\text { Borrowed } \\
\text { (Millions of Dollars) }\end{array}$ & $\begin{array}{l}\text { Number of } \\
\text { Borrowings }\end{array}$ & $\begin{array}{c}\text { Average Amount } \\
\text { Borrowed } \\
\text { (Millions of Dollars) }\end{array}$ & $\begin{array}{l}\text { Number of } \\
\text { Borrowings }\end{array}$ \\
\hline
\end{tabular}

Citigroup Global Markets Inc.

Deutsche Bank Securities Inc.

RBS Securities Inc.

Credit Suisse Securities (USA) LLC

Goldman, Sachs \& Co

Barclays Capital Inc.

Merrill Lynch Government Securities Inc.

UBS Securities LLC.

Morgan Stanley \& Co. Incorporated

Banc of America Securities LLC

Lehman Brothers Inc.

J.P. Morgan Securities LLC

BNP Paribas Securities Corp.

Countrywide Securities Corporation

Bear, Stearns \& Co., Inc.

Cantor Fitzgerald \& Co.

HSBC Securities (USA) Inc.

Dresdner Kleinwort Securities LLC

Mizuho Securities USA Inc.

Daiwa Securities America Inc.

$2,086.0$
$2,746.4$
$1,610.2$
$1,591.7$
$1,221.0$
$1,732.9$
609.5
437.6
517.3
837.5
394.6
574.7
718.2
96.7
0.0
60.6
0.0
32.5
0.0
0.0

$3,780.5$
$2,546.4$
$3,298.3$
$2,965.5$
$2,444.8$
$1,700.4$
$2,298.3$
$1,631.0$
$1,224.1$
819.8
$1,275.9$
580.1
99.4
59.7
34.5
10.3
51.7
0.0
0.0
0.0

$$
\begin{array}{r}
3,737.8 \\
1.1 \\
0.0 \\
3.2 \\
922.6 \\
873.3 \\
3,164.1 \\
75.3 \\
2,903.0 \\
1,359.3 \\
177.3 \\
6.4 \\
141.2 \\
163.9 \\
2,042.8 \\
59.7 \\
0.0 \\
0.2 \\
90.0 \\
0.9
\end{array}
$$

Notes: The table reports the average amount borrowed and the number of borrowings by dealer for the 33 TSLF Schedule 1 operations, 58 TSLF Schedule 2 operations, and 470 days the PDCF was open. Dealers are ordered in the table based on amount borrowed from the various facilities, weighted by borrowing term. Average borrowing amounts are calculated over all operation days even if a dealer was not a primary dealer for some of those days. 
Table IV. Dealer Financial Condition Summary Statistics

\begin{tabular}{|c|c|c|c|c|c|c|}
\hline & Mean & $\begin{array}{c}\text { Standard } \\
\text { Deviation }\end{array}$ & Minimum & Maximum & $\begin{array}{c}\text { Average Standard } \\
\text { Deviation of the Cross- } \\
\text { Section } \\
\end{array}$ & $\begin{array}{c}\text { Average Standard } \\
\text { Deviation of the Time } \\
\text { Series } \\
\end{array}$ \\
\hline Equity return $(\%)$ & -50.8 & 26.0 & -99.9 & 4.9 & 23.1 & 14.7 \\
\hline Quasi-leverage & 42.2 & 50.6 & 4.7 & 682.5 & 38.8 & 28.1 \\
\hline MMF non-Fed eligible collateral (\%) & 19.5 & 17.2 & 0.0 & 61.3 & -- & -- \\
\hline
\end{tabular}

Notes: The table reports summary statistics of dealer financial conditions for March 16, 2008 through January 29, 2010. Cumulative equity returns are measured from

January 2, 2007. Quasi-leverage is the ratio of a firm's quasi-market value of assets (i.e., the market value of equity plus the book value of debt) to market value of equity. MMF non-Fed eligible collateral is the share of collateral pledged to money market funds between December 1, 2007 and February 29 , 2008 that was not U.S. Treasury, agency debt, or agency mortgage-backed securities. The average standard deviation of the cross-section equals the average of the standard deviations calculated across dealers for each auction. The average standard deviation of the time series equals the average of the standard deviations calculated across auctions for each dealer. 
Table V. Explaining Whether a Dealer Participates

\begin{tabular}{|c|c|c|c|c|c|c|c|c|c|}
\hline & \multicolumn{3}{|c|}{ TSLF Schedule 1} & \multicolumn{3}{|c|}{ TSLF Schedule 2} & \multicolumn{3}{|c|}{ PDCF } \\
\hline & $(1)$ & $(2)$ & $(3)$ & (4) & $(5)$ & $(6)$ & $(7)$ & $(8)$ & $(9)$ \\
\hline Equity return & $\begin{array}{l}-0.447 * \\
(0.218)\end{array}$ & & $\begin{array}{l}-0.205^{\mathrm{j}} \\
(0.278)\end{array}$ & $\begin{array}{c}-0.774 * * * \\
(0.223)\end{array}$ & & $\begin{array}{c}-0.640 * * \mathrm{jij} \\
(0.244)\end{array}$ & $\begin{array}{l}-0.271 * \\
(0.152)\end{array}$ & & $\begin{array}{c}-0.348 * * \mathrm{ji} \\
(0.147)\end{array}$ \\
\hline 10/Quasi-leverage & & $\begin{array}{c}-0.427 * * \\
(0.168)\end{array}$ & $\begin{array}{l}-0.314^{\mathrm{j}} \\
(0.223)\end{array}$ & & $\begin{array}{c}-0.533^{* * *} \\
(0.173)\end{array}$ & $\begin{array}{l}-0.180^{\mathrm{ijj}} \\
(0.165)\end{array}$ & & $\begin{array}{c}-0.064 \\
(0.098)\end{array}$ & $\begin{array}{l}0.106 * \mathrm{jj} \\
(0.056)\end{array}$ \\
\hline Time fixed effects & YES & YES & YES & YES & YES & YES & YES & YES & YES \\
\hline Constant & $\begin{array}{c}0.597 * * * \\
(0.145)\end{array}$ & $\begin{array}{c}0.938 * * * \\
(0.127)\end{array}$ & $\begin{array}{c}0.824 * * * \\
(0.219)\end{array}$ & $\begin{array}{c}0.587 * * * \\
(0.138)\end{array}$ & $\begin{array}{c}1.110 * * * \\
(0.086)\end{array}$ & $\begin{array}{c}0.723 * * * \\
(0.155)\end{array}$ & $\begin{array}{c}0.113 \\
(0.095)\end{array}$ & $(0.127)$ & $\begin{array}{c}0.033 \\
(0.097)\end{array}$ \\
\hline Observations & 534 & 533 & 533 & 912 & 911 & 911 & 7,286 & 7,277 & 7,277 \\
\hline Adjusted R-squared & 0.300 & 0.308 & 0.311 & 0.314 & 0.275 & 0.317 & 0.193 & 0.159 & 0.198 \\
\hline
\end{tabular}

Notes: The table reports the results of OLS participation regressions for the TSLF and PDCF. The TSLF Schedule 1 (Schedule 2) dependent variable is an indicator variable equal to one if a dealer submitted a bid in a Schedule 1 (Schedule 2) auction and zero otherwise. The PDCF dependent variable is an indicator variable equal to one if a dealer borrowed from the PDCF on a given day and zero otherwise. Cumulative equity returns are calculated for each firm from January 2, 2007 to the day preceding each operation. Quasi-leverage is the ratio of a firm's quasi-market value of assets (i.e., the market value of equity plus the book value of debt) to market value of equity as of the day preceding each operation. Standard errors clustered by dealer are reported in parentheses. Coefficients marked ***, **, and * are significant at the $1 \%, 5 \%$ and $10 \%$ levels, respectively. Equity return and quasi-leverage coefficients marked $\mathrm{jjj}$, $\mathrm{jj}$, and $\mathrm{j}$ are jointly significant at the $1 \%, 5 \%$ and $10 \%$ levels, respectively. 
Table VI. Explaining Whether a Dealer Participates (without Time Fixed Effects)

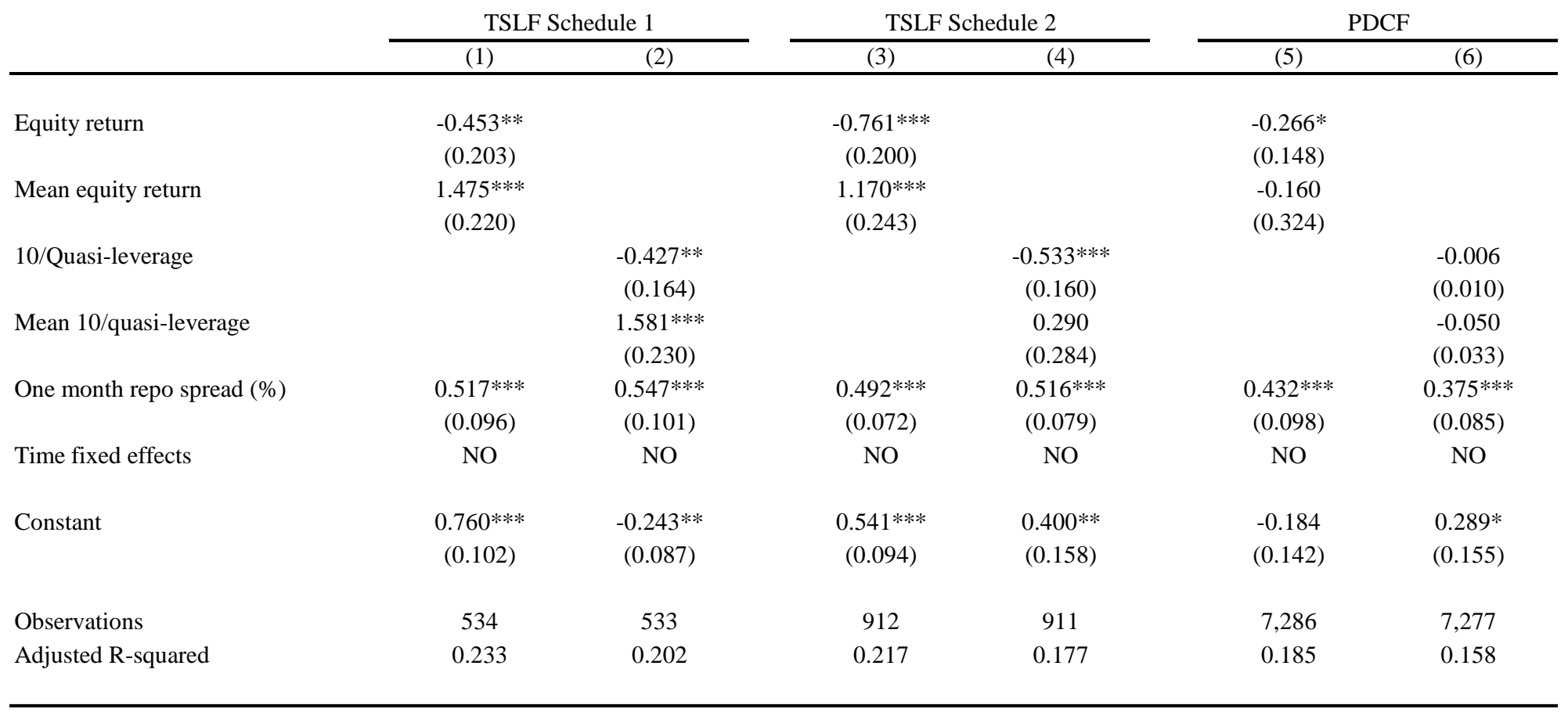

Notes: The table reports the results of OLS participation regressions for the TSLF and PDCF. The TSLF Schedule 1 (Schedule 2) dependent variable is an indicator variable equal to one if a dealer submitted a bid in a Schedule 1 (Schedule 2) auction and zero otherwise. The PDCF dependent variable is an indicator variable equal to one if a dealer borrowed from the PDCF on a given day and zero otherwise. Cumulative equity returns are calculated for each firm from January 2, 2007 to the day preceding each operation. Quasi-leverage is the ratio of a firm's quasi-market value of assets (i.e., the market value of equity plus the book value of debt) to market value of equity as of the day preceding each operation. Mean cumulative equity return and mean quasileverage are auction-level averages across all dealers. The repo spread is the difference between the one month repo rate for agency MBS collateral and the one month repo rate for Treasury general collateral and is measured as of the morning preceding each operation. Standard errors clustered by dealer are reported in parentheses. Coefficients marked $* * *, * *$, and $*$ are significant at the $1 \%, 5 \%$ and $10 \%$ levels, respectively. 
Table VII. Explaining Bid/Borrowing Amounts, Conditional on Participation

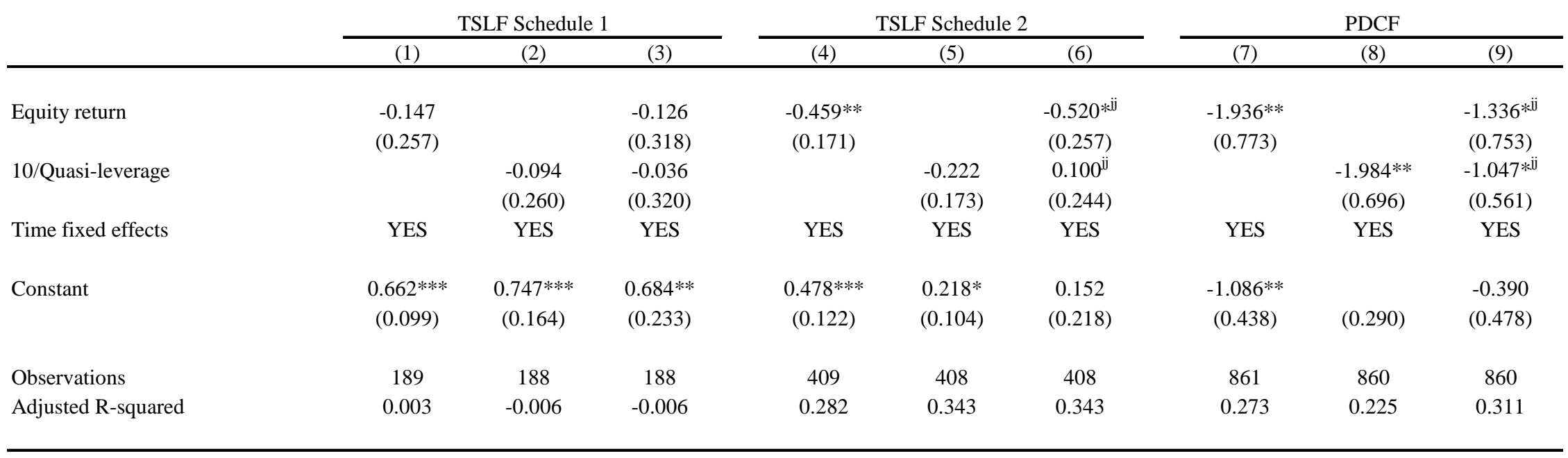

Notes: The table reports the results of OLS bid/borrowing amount regressions for the TSLF and PDCF. The TSLF Schedule 1 (Schedule 2) dependent variable is the ratio of the total amount a dealer bid in a given Schedule 1 (Schedule 2) auction to the maximum award amount. The PDCF dependent variable is the amount borrowed from the PDCF on a given day, in tens of billions of dollars. The dependent variables are conditional on participation and hence undefined when a dealer does not bid (TSLF) or borrow (PDCF). Cumulative equity returns are calculated for each firm from January 2, 2007 to the day preceding each operation. Quasi-leverage is the ratio of a firm's quasi-market value of assets (i.e., the market value of equity plus the book value of debt) to market value of equity as of the day preceding each operation. Standard errors clustered by dealer are reported in parentheses. Coefficients marked $* * *, * *$, and $*$ are significant at the $1 \%, 5 \%$ and $10 \%$ levels, respectively. Equity return and quasi-leverage coefficients marked jjj, $\mathrm{jj}$, and $\mathrm{j}$ are jointly significant at the $1 \%, 5 \%$ and $10 \%$ levels, respectively. 


\section{Table VIII. Explaining Bid Rates}

\begin{tabular}{|c|c|c|c|c|c|c|}
\hline & & LF Schedul & & & LF Schedu & \\
\hline & $(1)$ & $(2)$ & (3) & $(4)$ & $(5)$ & $(6)$ \\
\hline Equity return & -0.134 & & $0.039^{\mathrm{ij}}$ & $-2.210^{*}$ & & $-2.294^{\mathrm{jij}}$ \\
\hline & $(0.144)$ & & $(0.177)$ & $(1.076)$ & & $(1.772)$ \\
\hline 10/Quasi-leverage & & $-0.389 * *$ & $-0.408 * * \mathrm{j} \mathrm{j}$ & & $-1.324 *$ & $0.095^{\mathrm{jj}}$ \\
\hline & & $(0.137)$ & $(0.169)$ & & $(0.633)$ & $(1.360)$ \\
\hline Time fixed effects & YES & YES & YES & YES & YES & YES \\
\hline Constant & $0.103 * *$ & $0.312 * * *$ & $0.331 * * *$ & 0.271 & $1.639 * * *$ & 0.199 \\
\hline & $(0.039)$ & $(0.066)$ & $(0.111)$ & $(0.422)$ & $(0.458)$ & $(1.194)$ \\
\hline Observations & 189 & 188 & 188 & 409 & 408 & 408 \\
\hline Adjusted R-squared & 0.480 & 0.502 & 0.499 & 0.367 & 0.319 & 0.365 \\
\hline
\end{tabular}

Notes: The table reports results of OLS bid rate regressions for the TSLF. The dependent variable is the bid rate. If a dealer submitted two bids in an auction, then the dependent variable equals the average bid rate weighted by bid amount. The dependent variable is undefined if a dealer did not submit any bids. Cumulative equity returns are calculated for each firm from January 2, 2007 to the day preceding each auction. Quasi-leverage is the ratio of a firm's quasi-market value of assets (i.e., the market value of equity plus the book value of debt) to market value of equity as of the day preceding each auction. Standard errors clustered by dealer are reported in parentheses. Coefficients marked $* * *, * *$, and $*$ are significant at the $1 \%, 5 \%$ and $10 \%$ levels, respectively. Equity return and quasi-leverage coefficients marked jjj, jj, and $\mathrm{j}$ are jointly significant at the $1 \%, 5 \%$ and $10 \%$ levels, respectively. 
Table IX. Summary Statistics of Collateral Pledged Against Borrowings

Panel A: TSLF Schedule 2 Distribution by Collateral Rating

\begin{tabular}{|c|c|c|c|c|c|}
\hline Dealer & Aaa/AAA & $\mathrm{Aa} / \mathrm{AA}$ & A & $\mathrm{Baa} / \mathrm{BBB}$ & Commercial Paper \\
\hline Citigroup Global Markets Inc. & 88.5 & 5.0 & 3.7 & 2.4 & 0.4 \\
\hline Deutsche Bank Securities Inc. & 73.5 & 4.6 & 8.2 & 8.4 & 5.3 \\
\hline RBS Securities Inc. & 75.4 & 4.3 & 3.6 & 3.6 & 13.1 \\
\hline Credit Suisse Securities (USA) LLC & 54.7 & 4.6 & 14.3 & 20.8 & 5.5 \\
\hline Goldman, Sachs \& Co. & 88.3 & 5.3 & 3.1 & 3.3 & 0.0 \\
\hline Barclays Capital Inc. & 52.7 & 9.7 & 15.9 & 21.7 & 0.0 \\
\hline Merrill Lynch Government Securities Inc. & 80.4 & 7.5 & 3.4 & 7.4 & 1.3 \\
\hline UBS Securities LLC. & 84.9 & 3.2 & 6.0 & 5.9 & 0.0 \\
\hline Morgan Stanley \& Co. Incorporated & 51.0 & 11.3 & 5.3 & 2.9 & 29.5 \\
\hline Banc of America Securities LLC & 90.9 & 5.0 & 2.3 & 1.7 & 0.0 \\
\hline Lehman Brothers Inc. & 100.0 & 0.0 & 0.0 & 0.0 & 0.0 \\
\hline J.P. Morgan Securities LLC & 80.2 & 1.7 & 1.8 & 2.2 & 14.2 \\
\hline BNP Paribas Securities Corp. & 93.2 & 0.4 & 4.2 & 2.2 & 0.0 \\
\hline Countrywide Securities Corporation & 100.0 & 0.0 & 0.0 & 0.0 & 0.0 \\
\hline Bear, Stearns \& Co., Inc. & 100.0 & 0.0 & 0.0 & 0.0 & 0.0 \\
\hline Cantor Fitzgerald \& Co. & 100.0 & 0.0 & 0.0 & 0.0 & 0.0 \\
\hline HSBC Securities (USA) Inc. & 60.7 & 13.9 & 17.7 & 7.2 & 0.5 \\
\hline Dresdner Kleinwort Securities LLC & NA & NA & NA & NA & NA \\
\hline Mizuho Securities USA Inc. & NA & NA & NA & NA & NA \\
\hline Daiwa Securities America Inc. & NA & NA & NA & NA & NA \\
\hline
\end{tabular}

Panel B: TSLF Schedule 2 Distribution by Collateral Type

Dealer

Treasury \& Agency Debt

MBS-CMO:

Citigroup Global Markets Inc.

Deutsche Bank Securities Inc.

RBS Securities Inc.

Credit Suisse Securities (USA) LLC

Goldman, Sachs \& Co

Barclays Capital Inc.

Merrill Lynch Government Securities Inc.

UBS Securities LLC.

Morgan Stanley \& Co. Incorporated

Banc of America Securities LLC

Lehman Brothers Inc

J.P. Morgan Securities LLC

BNP Paribas Securities Corp.

Countrywide Securities Corporation

Bear, Stearns \& Co., Inc.

Cantor Fitzgerald \& Co.

HSBC Securities (USA) Inc.

Dresdner Kleinwort Securities LLC

Mizuho Securities USA Inc.

Agency Backed

MBS-CMO: Other

Asset-Backed

Corporate

Municipal Other

\begin{tabular}{cc}
2.0 & 63.0 \\
0.0 & 8.2 \\
0.1 & 46. \\
0.3 & 28.5 \\
0.0 & 68.4 \\
0.2 & 8.4 \\
0.3 & 49.4 \\
2.1 & 18.8 \\
0.6 & 15. \\
0.0 & 16.9 \\
0.0 & 58.3 \\
0.0 & 13. \\
11.6 & 17.6 \\
4.3 & 58.4 \\
0.0 & 0.0 \\
0.0 & 100. \\
7.0 & 0.3 \\
NA & NA \\
NA & NA \\
NA & NA \\
& \\
\hline
\end{tabular}

$\begin{array}{cc}17.9 & 3.3 \\ 54.1 & 17 . \\ 22.4 & 13 . \\ 20.9 & 10 . \\ 16.1 & 4.9 \\ 18.6 & 29 . \\ 19.4 & 16 . \\ 60.6 & 9.2 \\ 25.7 & 12 . \\ 71.9 & 6.5 \\ 35.0 & 6.6 \\ 69.6 & 1.6 \\ 70.8 & 0.0 \\ 35.6 & 1.7 \\ 100.0 & 0.0 \\ 0.0 & 0.0 \\ 15.5 & 33 . \\ \text { NA } & \text { NA } \\ \text { NA } & \text { NA } \\ \text { NA } & \text { NA } \\ \end{array}$

$\begin{array}{cc}3.3 & 1.4 \\ 17.4 & 20.3 \\ 13.2 & 17.4 \\ 10.5 & 39.6 \\ 4.9 & 4.7 \\ 29.9 & 41.3 \\ 16.3 & 6.6 \\ 9.2 & 8.7 \\ 12.8 & 37.4 \\ 6.5 & 0.6 \\ 6.6 & 0.0 \\ 1.6 & 15.0 \\ 0.0 & 0.0 \\ 1.7 & 0.0 \\ 0.0 & 0.0 \\ 0.0 & 0.0 \\ 33.1 & 15 . \\ \text { NA } & \text { NA } \\ \text { NA } & \text { NA } \\ \text { NA } & \text { NA } \\ & \end{array}$

$\begin{array}{ccc}1.4 & 12.4 & 0.1 \\ 20.3 & 0.0 & 0.0 \\ 17.4 & 0.0 & 0.0 \\ 39.6 & 0.2 & 0.0 \\ 4.7 & 6.0 & 0.0 \\ 41.3 & 1.5 & 0.0 \\ 6.6 & 8.0 & 0.0 \\ 8.7 & 0.4 & 0.0 \\ 37.4 & 7.7 & 0.0 \\ 0.6 & 4.1 & 0.0 \\ 0.0 & 0.0 & 0.0 \\ 15.0 & 0.0 & 0.0 \\ 0.0 & 0.0 & 0.0 \\ 0.0 & 0.0 & 0.0 \\ 0.0 & 0.0 & 0.0 \\ 0.0 & 0.0 & 0.0 \\ 15.6 & 26.1 & 2.4 \\ \text { NA } & \text { NA } & \text { NA } \\ \text { NA } & \text { NA } & \text { NA } \\ \text { NA } & \text { NA } & \text { NA }\end{array}$


Table IX. Summary Statistics of Collateral Pledged Against Borrowings (continued)

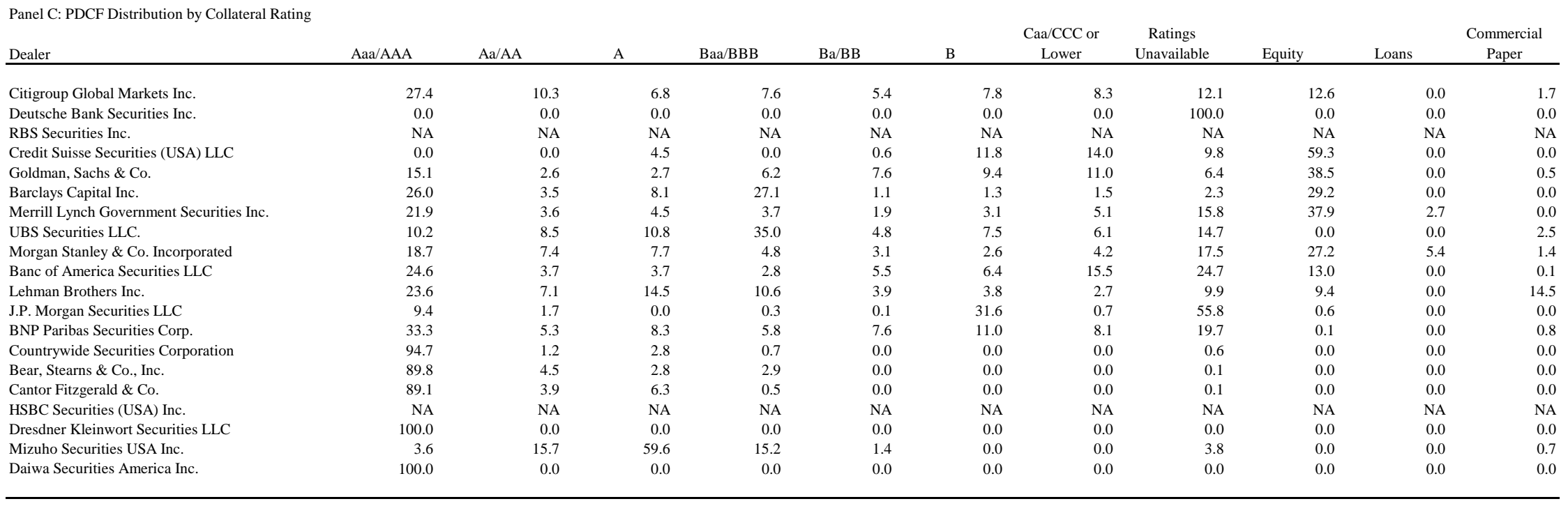

\begin{tabular}{|c|c|c|c|c|c|c|c|c|c|c|}
\hline Dealer & $\begin{array}{c}\text { Treasury \& } \\
\text { Agency Debt }\end{array}$ & $\begin{array}{c}\text { MBS-CMO: } \\
\text { Agency Backed }\end{array}$ & $\begin{array}{c}\text { MBS-CMO: } \\
\text { Other }\end{array}$ & Asset-Backed & Corporate & Municipal & Equity & Loans & International & Other \\
\hline Citigroup Global Markets Inc. & 3.3 & 0.0 & 8.1 & 8.9 & 25.7 & 28.2 & 12.6 & 0.0 & 0.0 & 13.1 \\
\hline Deutsche Bank Securities Inc. & 0.0 & 0.0 & 0.0 & 0.0 & 0.0 & 100.0 & 0.0 & 0.0 & 0.0 & 0.0 \\
\hline RBS Securities Inc. & NA & NA & NA & NA & NA & NA & NA & NA & NA & $\mathrm{NA}$ \\
\hline Credit Suisse Securities (USA) LLC & 0.0 & 0.0 & 5.1 & 29.5 & 6.1 & 0.0 & 59.3 & 0.0 & 0.0 & 0.0 \\
\hline Goldman, Sachs \& Co. & 0.0 & 7.4 & 14.1 & 12.9 & 23.9 & 1.9 & 38.5 & 0.0 & 0.0 & 1.4 \\
\hline Barclays Capital Inc. & 1.8 & 9.6 & 6.6 & 11.4 & 40.6 & 0.5 & 29.2 & 0.0 & 0.0 & 0.4 \\
\hline Merrill Lynch Government Securities Inc. & 0.3 & 0.2 & 2.6 & 6.1 & 12.1 & 13.5 & 37.9 & 2.7 & 0.0 & 24.7 \\
\hline UBS Securities LLC. & 2.3 & 3.1 & 12.2 & 38.8 & 40.3 & 3.3 & 0.0 & 0.0 & 0.0 & 0.0 \\
\hline Morgan Stanley \& Co. Incorporated & 1.0 & 0.9 & 3.6 & 6.6 & 18.8 & 32.6 & 27.2 & 5.4 & 0.2 & 3.8 \\
\hline Banc of America Securities LLC & 0.8 & 0.0 & 11.0 & 9.8 & 26.6 & 18.2 & 13.0 & 0.0 & 0.0 & 20.6 \\
\hline Lehman Brothers Inc. & 10.2 & 5.7 & 4.8 & 20.6 & 40.8 & 6.0 & 9.4 & 0.0 & 0.0 & 2.5 \\
\hline J.P. Morgan Securities LLC & 0.0 & 0.0 & 11.3 & 44.2 & 43.9 & 0.0 & 0.6 & 0.0 & 0.0 & 0.0 \\
\hline BNP Paribas Securities Corp. & 9.2 & 10.1 & 0.5 & 0.8 & 58.5 & 20.8 & 0.1 & 0.0 & 0.0 & 0.0 \\
\hline Countrywide Securities Corporation & 12.4 & 18.4 & 61.6 & 7.7 & 0.0 & 0.0 & 0.0 & 0.0 & 0.0 & 0.0 \\
\hline Bear, Stearns \& Co., Inc. & 0.0 & 54.5 & 32.1 & 13.1 & 0.4 & 0.0 & 0.0 & 0.0 & 0.0 & 0.0 \\
\hline Cantor Fitzgerald \& Co. & 0.7 & 9.4 & 0.4 & 89.4 & 0.1 & 0.0 & 0.0 & 0.0 & 0.0 & 0.0 \\
\hline HSBC Securities (USA) Inc. & NA & NA & NA & NA & NA & NA & NA & NA & NA & $\mathrm{NA}$ \\
\hline Dresdner Kleinwort Securities LLC & 0.0 & 0.0 & 0.0 & 100.0 & 0.0 & 0.0 & 0.0 & 0.0 & 0.0 & 0.0 \\
\hline Mizuho Securities USA Inc. & 0.1 & 0.1 & 0.0 & 1.7 & 97.1 & 0.0 & 0.0 & 0.0 & 1.0 & 0.0 \\
\hline Daiwa Securities America Inc. & 99.7 & 0.3 & 0.0 & 0.0 & 0.0 & 0.0 & 0.0 & 0.0 & 0.0 & 0.0 \\
\hline
\end{tabular}

Notes: The table reports the proportions of collateral pledged against TSLF Schedule 2 borrowings and PDCF borrowings, grouped by the ratings assigned to the collateral and by collateral type. The rating is based on a composite credit rating of the pledged collateral, based on ratings information used by the borrower's clearing bank. Dealers are ordered in the same manner as Table III. 


\section{Table X. Effects of Non-Fed Eligible Collateral}

\begin{tabular}{|c|c|c|c|c|c|c|c|c|}
\hline \multirow[b]{2}{*}{ Dependent Variable: Unconditional Bid Amount } & \multicolumn{4}{|c|}{ TSLF2 } & \multicolumn{4}{|c|}{ PDCF } \\
\hline & $(1)$ & $(2)$ & (3) & $(4)$ & $(5)$ & $(6)$ & (7) & $(8)$ \\
\hline Equity return & $\begin{array}{c}-0.511^{* * * *} \\
(0.104)\end{array}$ & $\begin{array}{c}-0.557 * * * * \\
(0.160)\end{array}$ & & & $\begin{array}{c}-0.414 * * * \\
(0.116)\end{array}$ & $\begin{array}{l}-0.006 \\
(0.172)\end{array}$ & & \\
\hline Equity return* non-Fed eligible & & $\begin{array}{c}0.216 \\
(0.629)\end{array}$ & & & & $\begin{array}{c}-1.889 * * \\
(0.819)\end{array}$ & & \\
\hline 10/Quasi-leverage & & & $\begin{array}{c}-0.310 * * \\
(0.116)\end{array}$ & $\begin{array}{l}-0.224 \\
(0.127)\end{array}$ & & & $\begin{array}{l}-0.177 \\
(0.118)\end{array}$ & $\begin{array}{c}0.033 \\
(0.076)\end{array}$ \\
\hline 10/Quasi-leverage $*$ non-Fed eligible & & & & $\begin{array}{l}-0.732 \\
(0.745)\end{array}$ & & & & $\begin{array}{c}-1.988 * * \\
(0.818)\end{array}$ \\
\hline Non-Fed eligible & $\begin{array}{c}0.329 * * \\
(0.149)\end{array}$ & $\begin{array}{c}0.430 * * \\
(0.189)\end{array}$ & $\begin{array}{c}0.402 * * \\
(0.167)\end{array}$ & $\begin{array}{c}0.761 \\
(0.529)\end{array}$ & $\begin{array}{c}0.393 * * \\
(0.138)\end{array}$ & $\begin{array}{l}-0.362 \\
(0.301)\end{array}$ & $\begin{array}{l}0.433^{*} \\
(0.212)\end{array}$ & $\begin{array}{c}1.577 * * \\
(0.558)\end{array}$ \\
\hline Time fixed effects & YES & YES & YES & YES & YES & YES & YES & YES \\
\hline Constant & $\begin{array}{c}0.164 \\
(0.107)\end{array}$ & $\begin{array}{c}0.143 \\
(0.115)\end{array}$ & $\begin{array}{c}0.464 * * * \\
(0.101)\end{array}$ & $\begin{array}{c}0.428 * * * \\
(0.113)\end{array}$ & $\begin{array}{c}-0.225 * * \\
(0.076)\end{array}$ & $\begin{array}{l}-0.066 \\
(0.066)\end{array}$ & $\begin{array}{c}0.011 \\
(0.047)\end{array}$ & $\begin{array}{l}-0.126 \\
(0.072)\end{array}$ \\
\hline Observations & 739 & 739 & 738 & 738 & 5,954 & 5,954 & 5,945 & 5,945 \\
\hline Adjusted R-squared & 0.403 & 0.403 & 0.356 & 0.364 & 0.277 & 0.324 & 0.239 & 0.306 \\
\hline
\end{tabular}

Notes: The tables reports results of OLS bid amount regressions for the TSLF and PDCF. For each dealer and auction day, the TSLF dependent variable is the ratio of the total amount a dealer bid in a given auction to the maximum award amount. It is equal to zero if the dealer did not participate. The PDCF dependent variable is the amount borrowed from the PDCF on a given day, in tens of billions of dollars. Non-Fed eligible is the percent share of collateral each dealer pledged to money market funds between December 1, 2007 and February 29, 2008 that is not U.S. Treasury, agency debt, or agency mortgage-backed securities. Cumulative equity returns are calculated for each firm from January 2, 2007 to the day preceding each operation. Quasi-leverage is the ratio of a firm's quasi-market value of assets (i.e., the market value of equity plus the book value of debt) to market value of equity as of the day preceding each operation. Standard errors clustered by dealer are reported in parentheses. Coefficients marked $* * *, * *$, and $*$ are significant at the $1 \%$, $5 \%$ and $10 \%$ levels, respectively. 


\begin{tabular}{|c|c|c|c|c|c|c|c|}
\hline Dealer & $\begin{array}{c}\text { Number of } \\
\text { Borrowing Days }\end{array}$ & $\begin{array}{c}\text { Number of } \\
\text { Spells }\end{array}$ & $\begin{array}{l}\text { Mean Spell } \\
\text { Length }\end{array}$ & $\begin{array}{l}\text { Median Spell } \\
\text { Length }\end{array}$ & $\begin{array}{l}\text { Minimum Spell } \\
\text { Length }\end{array}$ & $\begin{array}{l}\text { Maximum Spell } \\
\text { Length }\end{array}$ & $\begin{array}{c}\text { Average PDCF } \\
\text { Borrowing } \\
\text { (Millions of Dollars) }\end{array}$ \\
\hline Citigroup Global Markets Inc. & 174 & 3 & 58.0 & 14 & 8 & 152 & $3,737.8$ \\
\hline Deutsche Bank Securities Inc. & 1 & 1 & 1.0 & 1 & 1 & 1 & 1.1 \\
\hline RBS Securities Inc. & 0 & 0 & N/A & N/A & N/A & N/A & 0.0 \\
\hline Credit Suisse Securities (USA) LLC & 2 & 1 & 2.0 & 2 & 2 & 2 & 3.2 \\
\hline Goldman, Sachs \& Co. & 52 & 2 & 26.0 & 26 & 1 & 51 & 922.6 \\
\hline Barclays Capital Inc. & 74 & 3 & 24.7 & 24.0 & 1 & 49 & 873.3 \\
\hline Merrill Lynch Government Securities Inc. & 99 & 4 & 24.8 & 2 & 1 & 95 & $3,164.1$ \\
\hline UBS Securities LLC. & 8 & 1 & 8.0 & 8 & 8 & 8 & 75.3 \\
\hline Morgan Stanley \& Co. Incorporated & 122 & 7 & 17.4 & 1 & 1 & 116 & $2,903.0$ \\
\hline Banc of America Securities LLC & 118 & 4 & 29.5 & 22 & 1 & 74 & $1,359.3$ \\
\hline Lehman Brothers Inc. & 10 & 3 & 3.3 & 3 & 1 & 6 & 177.3 \\
\hline J.P. Morgan Securities LLC & 3 & 3 & 1.0 & 1 & 1 & 1 & 6.4 \\
\hline BNP Paribas Securities Corp. & 43 & 9 & 4.8 & 3 & 1 & 13 & 141.2 \\
\hline Countrywide Securities Corporation & 75 & 1 & 75.0 & 75.0 & 75 & 75 & 163.9 \\
\hline Bear, Stearns \& Co., Inc. & 69 & 1 & 69.0 & 69.0 & 69 & 69 & $2,042.8$ \\
\hline Cantor Fitzgerald \& Co. & 61 & 1 & 61.0 & 61 & 61 & 61 & 59.7 \\
\hline HSBC Securities (USA) Inc. & 0 & 0 & N/A & N/A & N/A & N/A & 0.0 \\
\hline Dresdner Kleinwort Securities LLC & 1 & 1 & 1.0 & 1 & 1 & 1 & 0.2 \\
\hline Mizuho Securities USA Inc. & 108 & 2 & 54.0 & 54 & 1 & 107 & 90.0 \\
\hline Daiwa Securities America Inc. & 1 & 1 & 1.0 & 1 & 1 & 1 & 0.9 \\
\hline All Firms & 242 & 48 & 21.3 & 1.5 & 1 & 152 & $15,722.0$ \\
\hline
\end{tabular}

Notes: The table provides summary statistics on the distribution of the length (in business days) of PDCF borrowing spells by bank. The number of borrowing days is the number of days on which the dealer borrowed from the PDCF. For all firms, the number of borrowing days is the number of days on which at least one dealer borrowed from the PDCF. A spell is a period of time over which a borrower has a positive PDCF balance every day during the period. Average borrowing amounts are calculated over all operation days even if a dealer was not a primary dealer for some of those days. 
Figure 1A: TSLF Schedule 1 Award Amount vs. Return

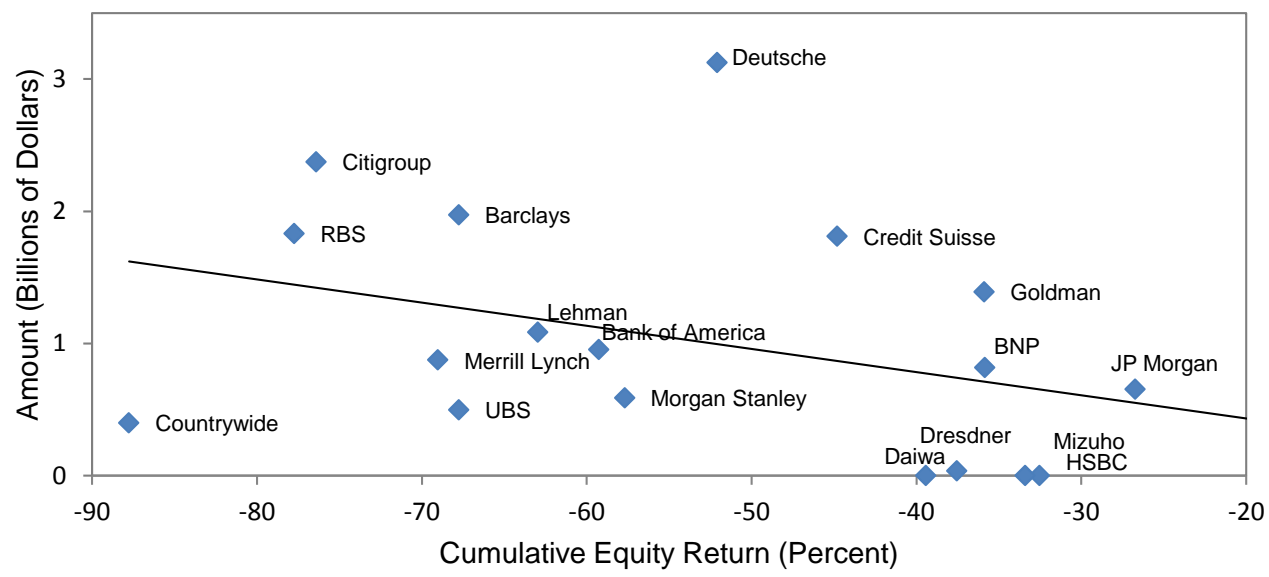

Figure 1B: TSLF Schedule 2 Award Amount vs. Return

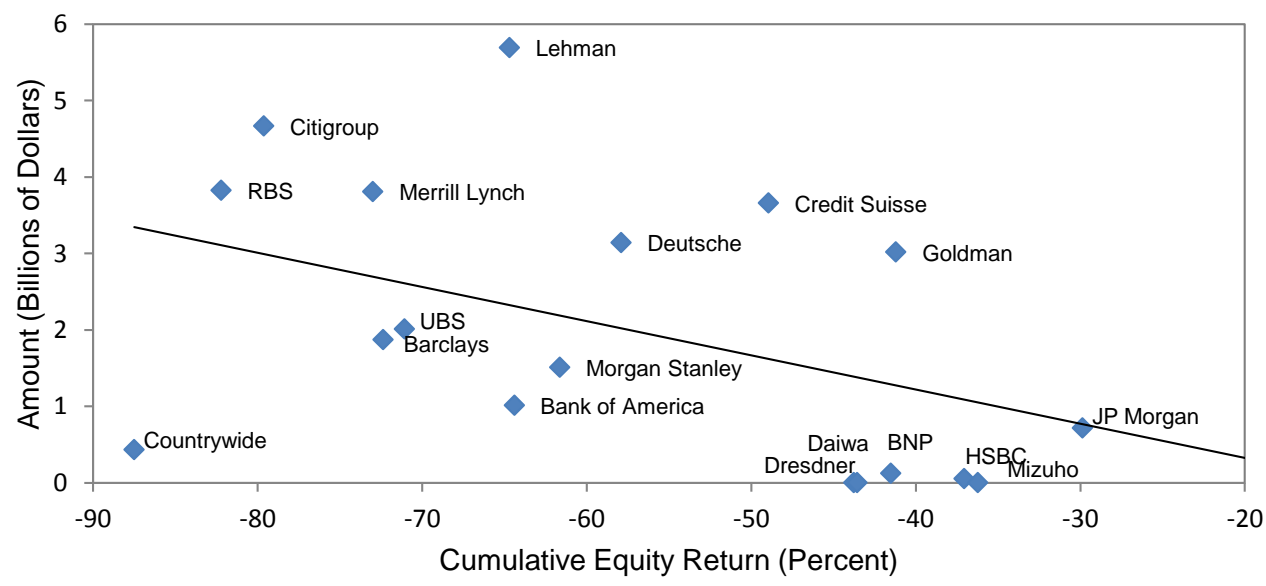

Figure 1C: PDCF Borrowing Amount vs. Return

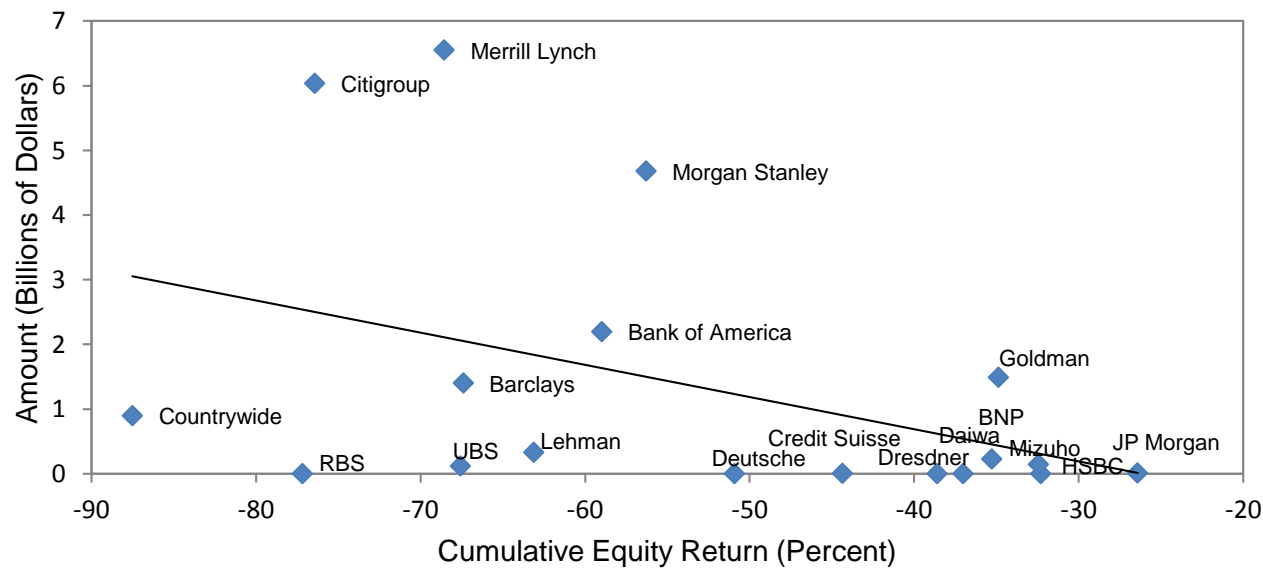

Notes: The figures plot dealers' average borrowing amounts from the TSLF (Schedules 1 and 2) and PDCF against their mean cumulative equity returns for the March 17, 2008 to May 12, 2009 sample period, excluding all activity for Bear Stearns and Cantor Fitzgerald, and, for the period after September 15, 2008, Lehman Brothers. Averages are calculated over all operations, including those in which a given dealer did not borrow. Equity returns are cumulated from January 2, 2007 and then averaged over the sample period. The lines indicate the best fit for the scatter points. 
Figure 2: Repo Spreads

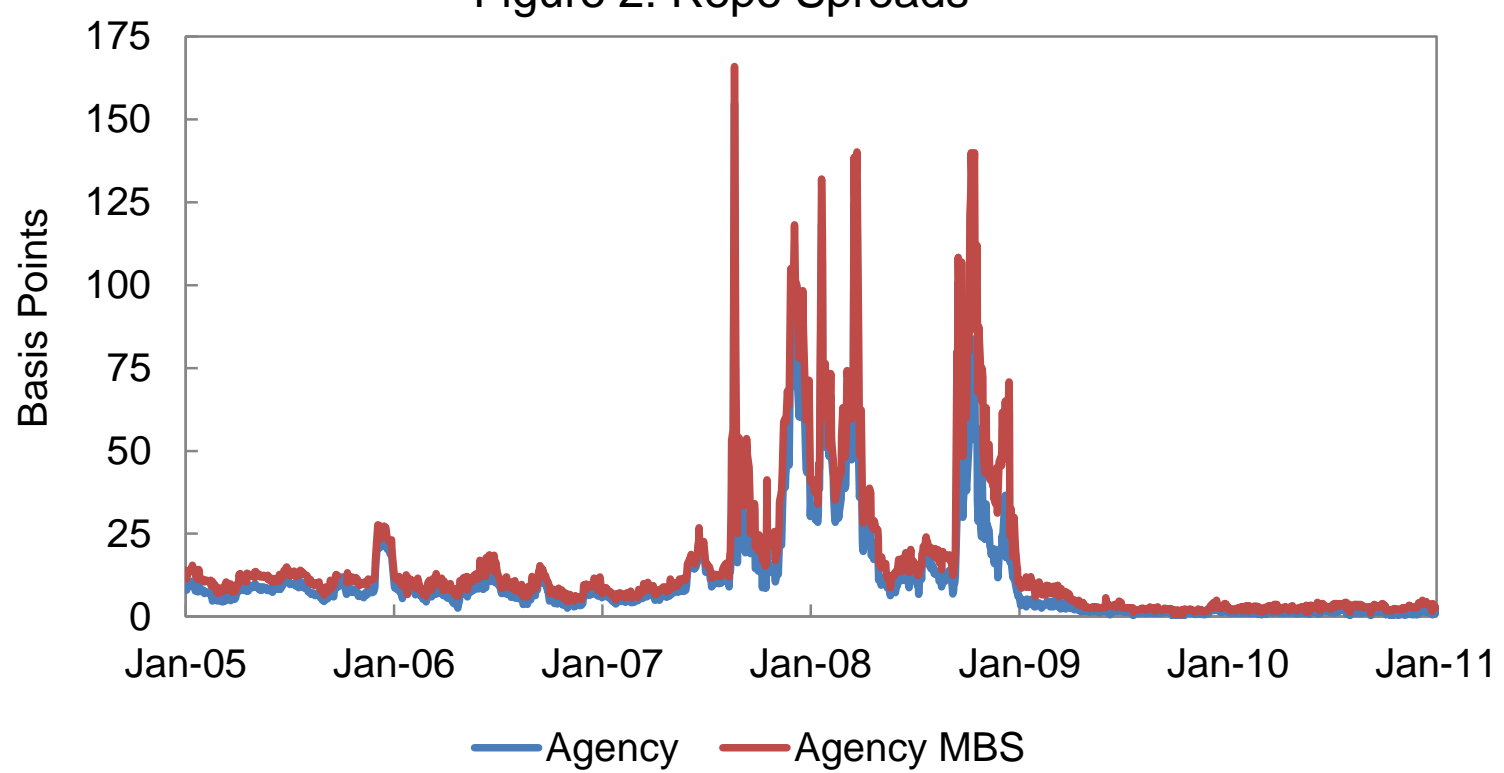

Note: The figure plots one month agency and agency MBS repo spreads to the one month Treasury general collateral repo rate.

Figure 3: Amounts Outstanding

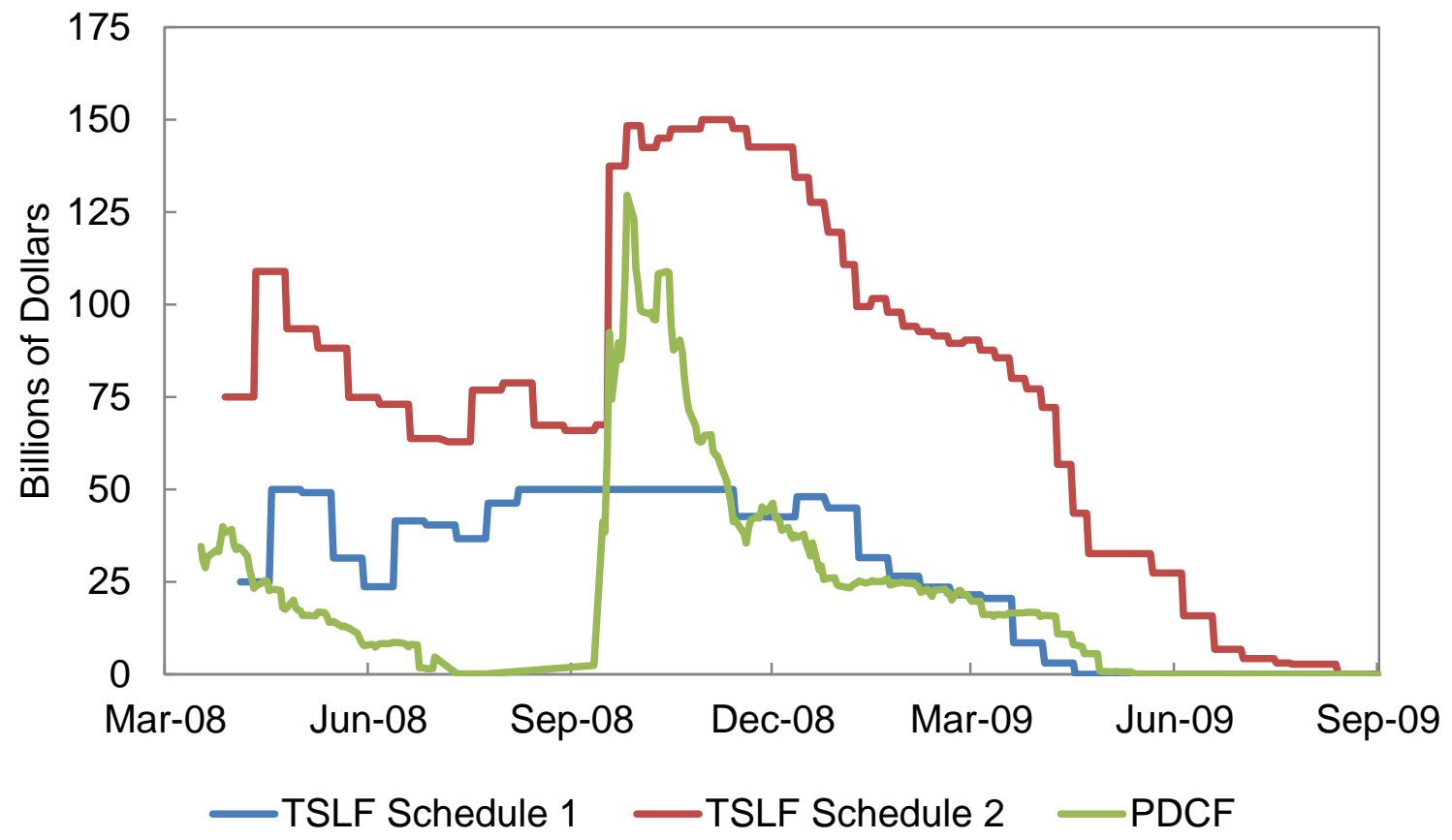

Notes: The figure plots amounts outstanding over time for the TSLF (by schedule) and PDCF. The last TSLF auction was held January 7, 2010, but there was no borrowing after the July 16, 2009 auction. The PDCF was open until February 1, 2010, but there was no borrowing after May 12, 2009. 
Figure 4A: Dealer Bid Rates in TSLF Schedule 1 Auctions

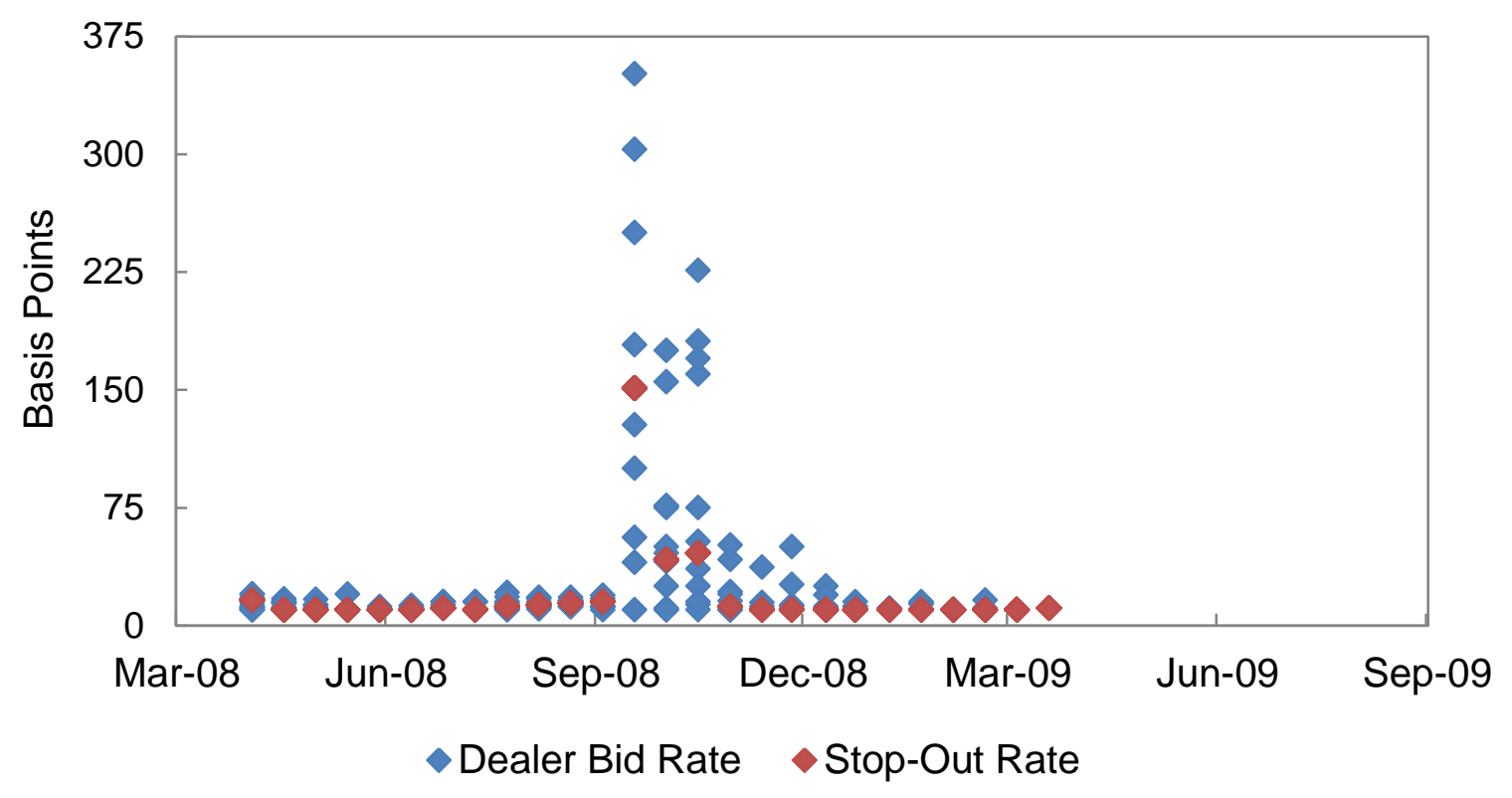

Figure 4B: Dealer Bid Rates in TSLF Schedule 2 Auctions

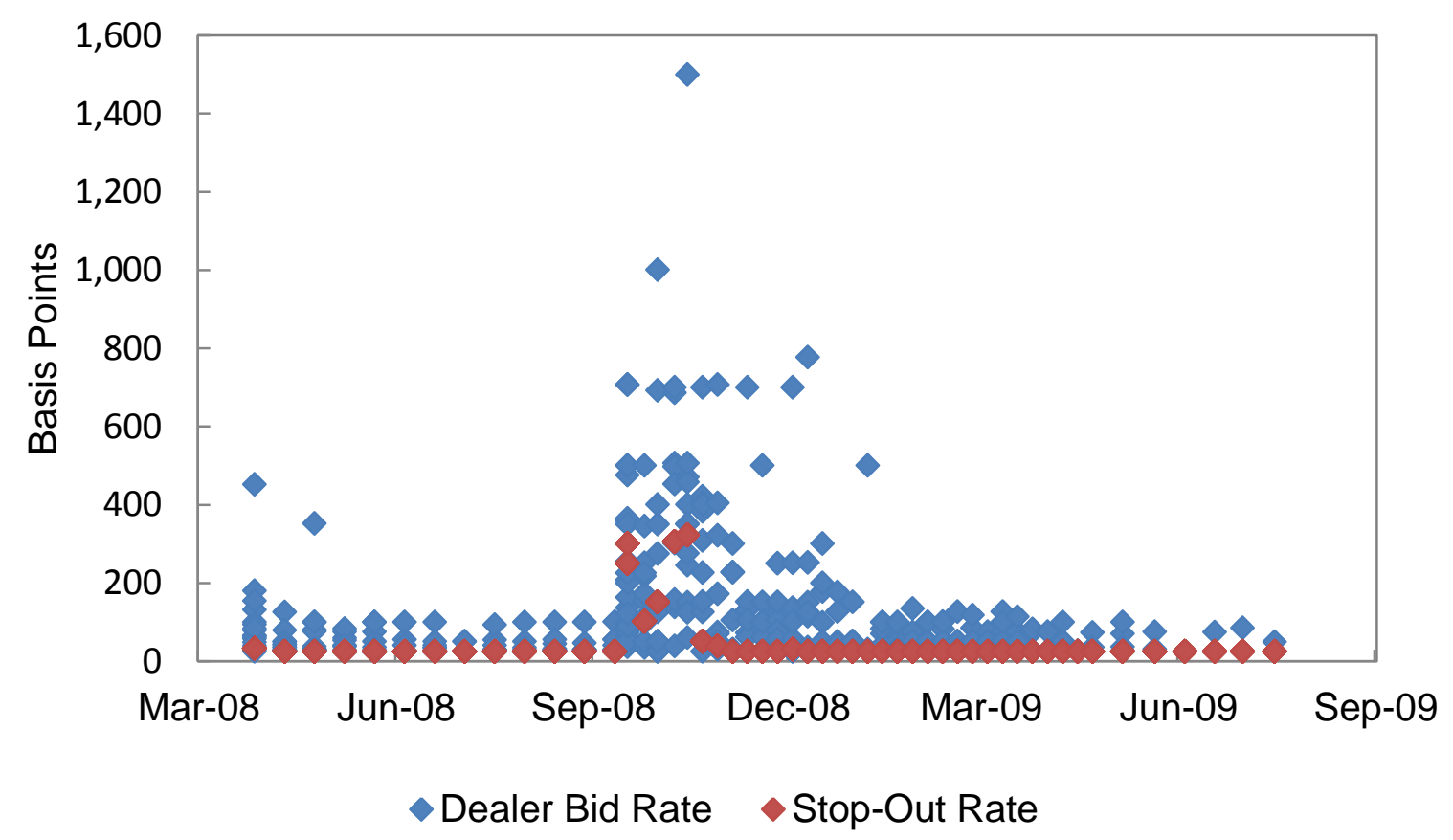

Notes: The figures plot dealer bid rates in TSLF Schedule 1 (Panel A) and Schedule 2 (Panel B) auctions. Each blue diamond represents a dealer's average bid rate, weighted by bid amount. Each red diamond represents an auction's stop-out rate. The last Schedule 1 (Schedule 2) auction was held June 25, 2009 (January 7, 2010), but no bids were made after the March 19, 2009 (July 16, 2009) auction. 
Figure 5: Citigroup Borrowing from PDCF and TSLF

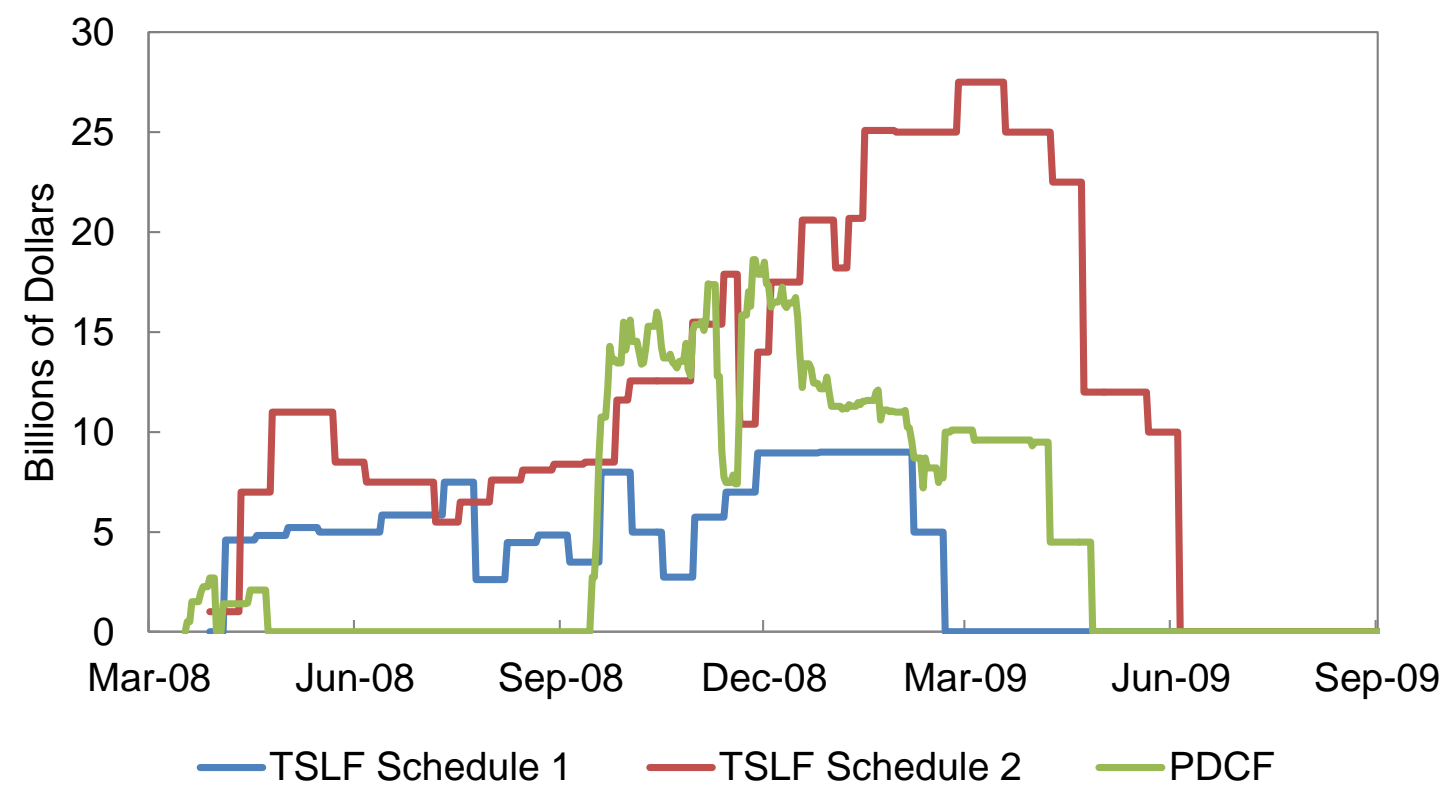

Notes: The figure plots Citigroup's outstanding borrowing from the TSLF (Schedules 1 and 2) and PDCF.

Figure 6: PDCF and TSLF Borrowing Costs

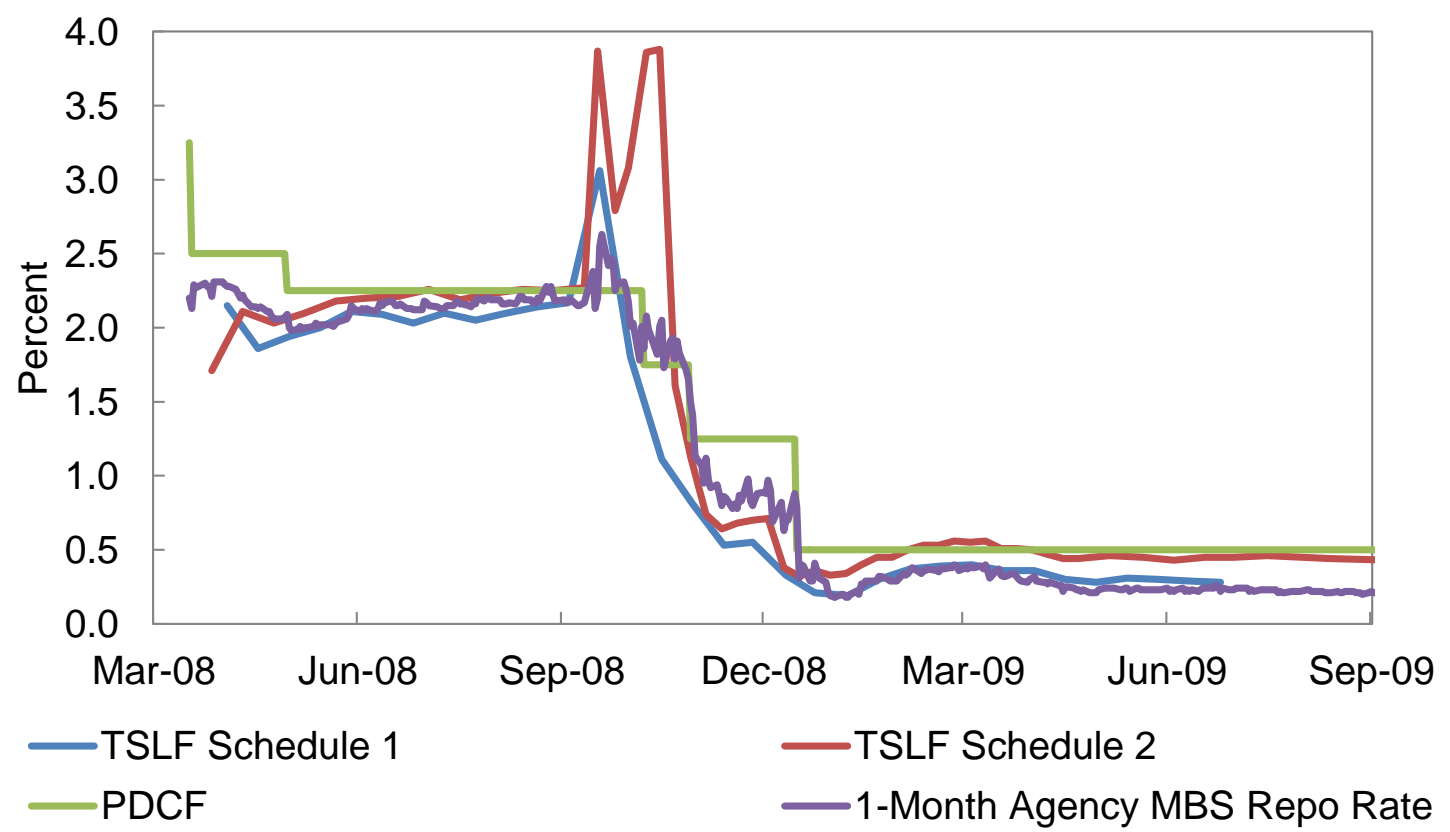

Notes: The figure plots borrowing costs in the TSLF (Schedules 1 and 2) and PDCF, as well as the one-month agency MBS repo rate. TSLF borrowing costs are calculated as the one-month Treasury general collateral repo rate plus the stop-out rate for the given auction and schedule. PDCF borrowing costs equal the discount window primary credit rate. 
Figure 7A: Repo Liabilities Ratio vs. Return

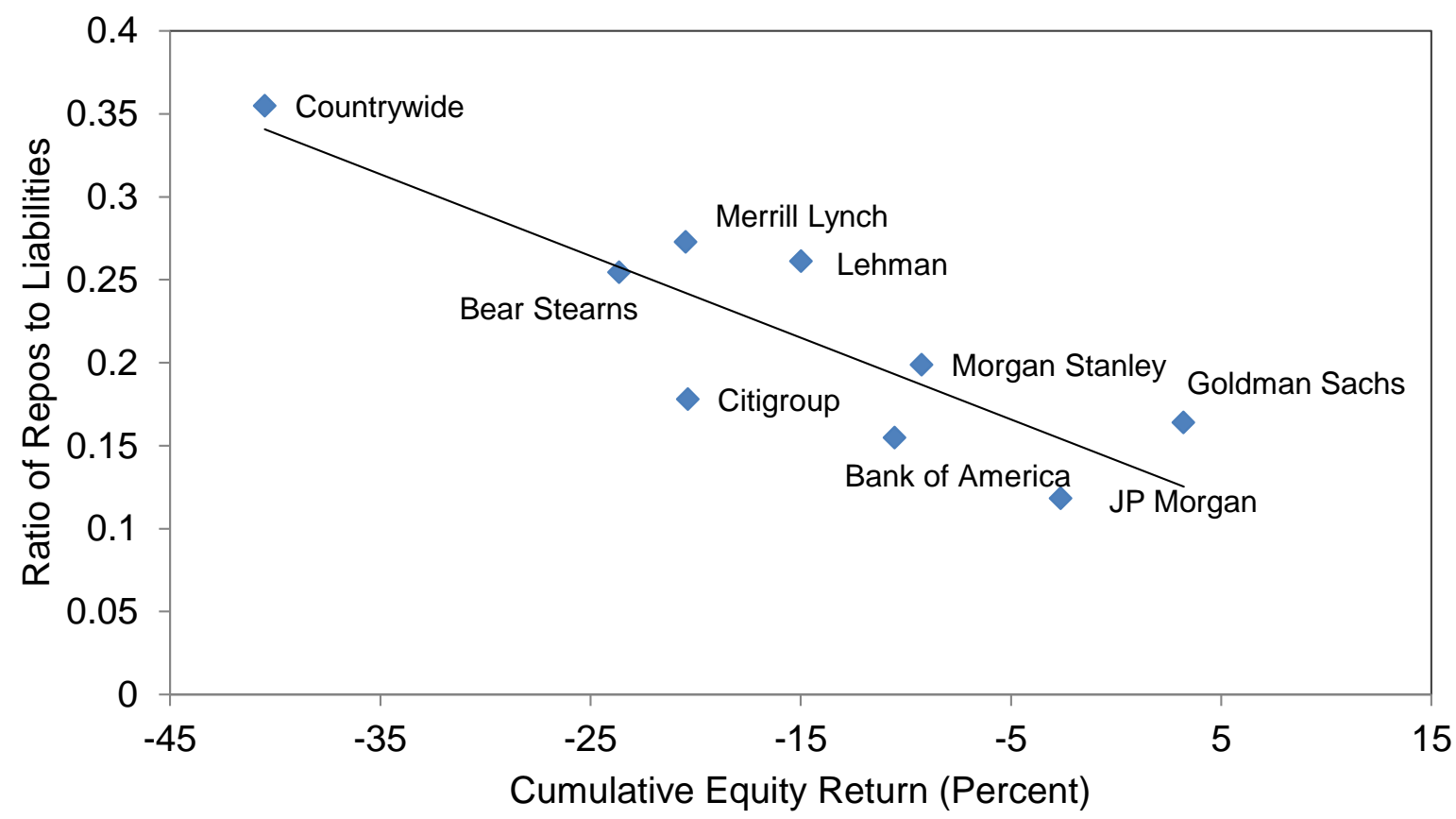

Figure 7B: Repo Liabilities Ratio vs. Quasi-Leverage

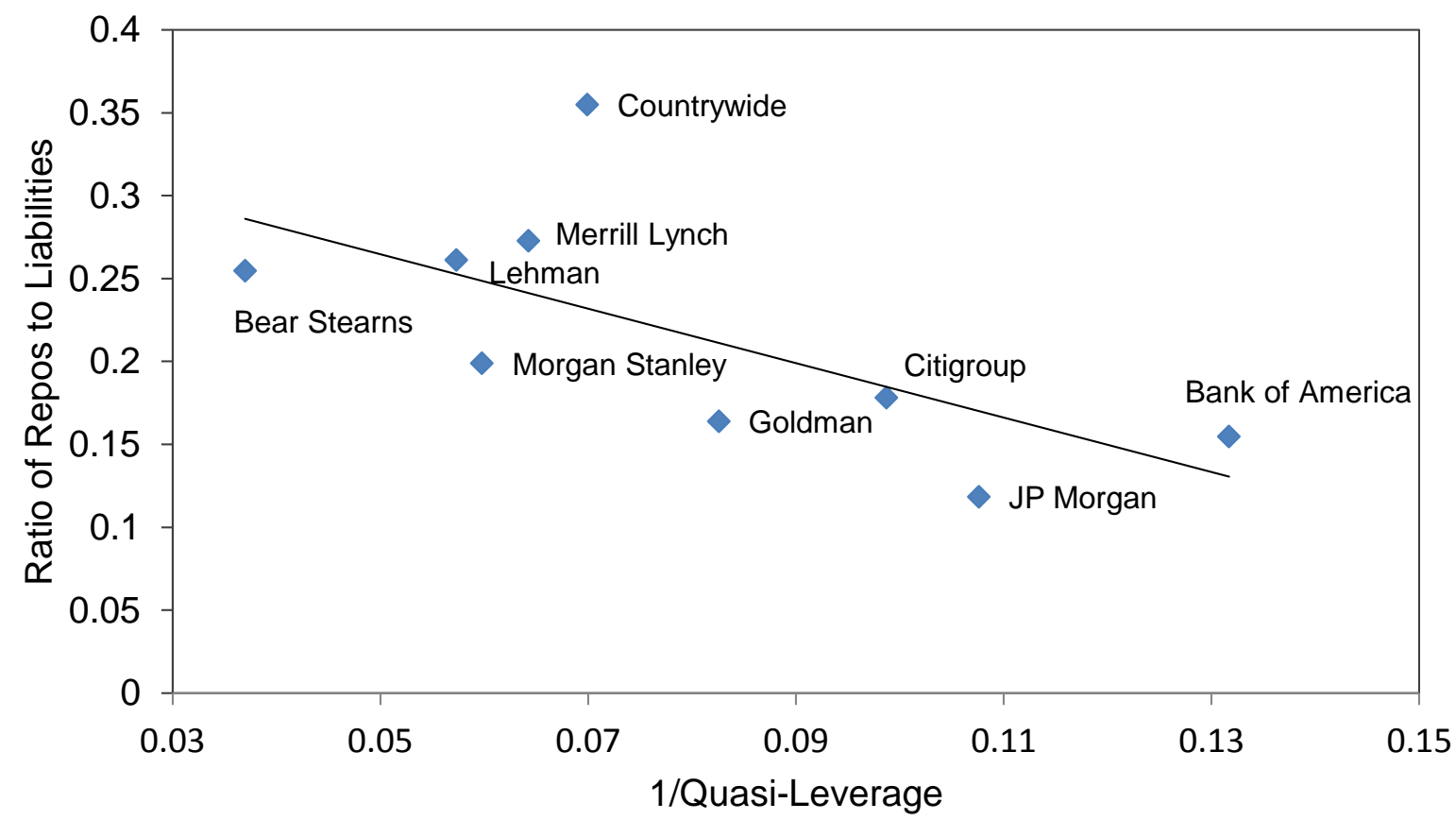

Notes: The figures plot dealers' average repo to liabilities ratio against their average cumulative equity return and quasi leverage between January 2, 2007 and March 16, 2008. The ratios are derived from quarterly SNL balance sheets and are calculated as the sum of securities sold to repurchase and fed funds borrowings, divided by total liabilities. Equity returns are cumulated from January 2, 2007. Quasi-leverage is the ratio of a firm's quasi-market value of assets (i.e., the market value of equity plus the book value of debt) to market value of equity. Due to differing accounting standards, foreign firms are excluded. 
Table A1. TSLF Auction Results

\begin{tabular}{|c|c|c|c|c|c|c|c|}
\hline Auction Date & Schedule & Term & Offer Amount & $\begin{array}{c}\text { Submitted } \\
\text { Amount }\end{array}$ & $\begin{array}{c}\text { Accepted } \\
\text { Amount } \\
\end{array}$ & Bid-to-Cover & Stop-Out Rate \\
\hline $3 / 27 / 2008$ & 2 & 28 & 75 & 86.1 & 75.0 & 1.15 & 33 \\
\hline 4/3/2008 & 1 & 28 & 25 & 46.9 & 25.0 & 1.88 & 16 \\
\hline 4/10/2008 & 2 & 28 & 50 & 34.0 & 34.0 & 0.68 & 25 \\
\hline 4/17/2008 & 1 & 28 & 25 & 35.1 & 25.0 & 1.40 & 10 \\
\hline $4 / 24 / 2008$ & 2 & 28 & 75 & 59.5 & 59.5 & 0.79 & 25 \\
\hline $5 / 1 / 2008$ & 1 & 28 & 25 & 24.1 & 24.1 & 0.96 & 10 \\
\hline $5 / 8 / 2008$ & 2 & 28 & 50 & 28.8 & 28.8 & 0.58 & 25 \\
\hline $5 / 15 / 2008$ & 1 & 28 & 25 & 7.2 & 7.2 & 0.29 & 10 \\
\hline $5 / 22 / 2008$ & 2 & 28 & 75 & 46.1 & 46.1 & 0.62 & 25 \\
\hline $5 / 29 / 2008$ & 1 & 28 & 25 & 16.4 & 16.4 & 0.66 & 10 \\
\hline 6/5/2008 & 2 & 31 & 50 & 26.9 & 26.9 & 0.54 & 25 \\
\hline $6 / 12 / 2008$ & 1 & 28 & 25 & 27.2 & 25.0 & 1.09 & 10 \\
\hline $6 / 19 / 2008$ & 2 & 28 & 75 & 36.8 & 36.8 & 0.49 & 25 \\
\hline $6 / 26 / 2008$ & 1 & 28 & 25 & 15.4 & 15.4 & 0.62 & 11 \\
\hline $7 / 3 / 2008$ & 2 & 25 & 50 & 26.1 & 26.1 & 0.52 & 25 \\
\hline $7 / 10 / 2008$ & 1 & 28 & 25 & 21.3 & 21.3 & 0.85 & 10 \\
\hline $7 / 17 / 2008$ & 2 & 28 & 75 & 51.8 & 50.8 & 0.69 & 25 \\
\hline $7 / 24 / 2008$ & 1 & 28 & 25 & 51.7 & 25.0 & 2.07 & 12 \\
\hline $7 / 31 / 2008$ & 2 & 28 & 50 & 28.1 & 28.1 & 0.56 & 25 \\
\hline 8/7/2008 & 1 & 28 & 25 & 39.5 & 25.0 & 1.58 & 13 \\
\hline $8 / 14 / 2008$ & 2 & 28 & 75 & 39.3 & 39.3 & 0.52 & 25 \\
\hline $8 / 21 / 2008$ & 1 & 28 & 25 & 44.7 & 25.0 & 1.79 & 14 \\
\hline $8 / 28 / 2008$ & 2 & 28 & 50 & 26.7 & 26.7 & 0.53 & 25 \\
\hline 9/4/2008 & 1 & 28 & 25 & 45.0 & 25.0 & 1.80 & 15 \\
\hline 9/11/2008 & 2 & 28 & 75 & 40.9 & 40.9 & 0.54 & 25 \\
\hline 9/17/2008 & 2 & 14 & 35 & 64.4 & 35.0 & 1.84 & 250 \\
\hline 9/17/2008 & 2 & 28 & 35 & 71.3 & 35.0 & 2.04 & 300 \\
\hline 9/18/2008 & 1 & 28 & 25 & 49.6 & 25.0 & 1.98 & 151 \\
\hline $9 / 25 / 2008$ & 2 & 27 & 38 & 61.2 & 37.5 & 1.63 & 102 \\
\hline $10 / 1 / 2008$ & 2 & 28 & 35 & 66.7 & 35.0 & 1.90 & 151 \\
\hline $10 / 2 / 2008$ & 1 & 28 & 25 & 49.0 & 25.0 & 1.96 & 42 \\
\hline $10 / 9 / 2008$ & 2 & 27 & 38 & 62.8 & 37.5 & 1.67 & 305 \\
\hline $10 / 15 / 2008$ & 2 & 28 & 38 & 73.7 & 37.5 & 1.96 & 322 \\
\hline $10 / 16 / 2008$ & 1 & 28 & 25 & 44.0 & 25.0 & 1.76 & 46 \\
\hline $10 / 22 / 2008$ & 2 & 28 & 38 & 47.3 & 37.5 & 1.26 & 50 \\
\hline $10 / 29 / 2008$ & 2 & 29 & 38 & 53.1 & 37.5 & 1.42 & 38 \\
\hline $10 / 30 / 2008$ & 1 & 28 & 25 & 30.8 & 25.0 & 1.23 & 12 \\
\hline $11 / 5 / 2008$ & 2 & 28 & 38 & 43.0 & 37.5 & 1.15 & 25 \\
\hline $11 / 12 / 2008$ & 2 & 28 & 38 & 35.1 & 35.1 & 0.94 & 25 \\
\hline $11 / 13 / 2008$ & 1 & 28 & 25 & 17.6 & 17.6 & 0.70 & 10 \\
\hline $11 / 19 / 2008$ & 2 & 28 & 38 & 32.5 & 32.5 & 0.87 & 25 \\
\hline $11 / 26 / 2008$ & 1 & 28 & 25 & 31.0 & 25.0 & 1.24 & 10 \\
\hline $11 / 26 / 2008$ & 2 & 28 & 38 & 37.7 & 37.5 & 1.00 & 25 \\
\hline $12 / 3 / 2008$ & 2 & 29 & 38 & 45.6 & 37.5 & 1.21 & 31 \\
\hline $12 / 10 / 2008$ & 2 & 28 & 38 & 26.9 & 26.9 & 0.72 & 25 \\
\hline $12 / 11 / 2008$ & 1 & 28 & 25 & 23.0 & 23.0 & 0.92 & 10 \\
\hline $12 / 17 / 2008$ & 2 & 28 & 38 & 25.7 & 25.7 & 0.69 & 25 \\
\hline $12 / 24 / 2008$ & 1 & 28 & 25 & 22.0 & 22.0 & 0.88 & 10 \\
\hline
\end{tabular}




\begin{tabular}{|c|c|c|c|c|c|c|c|}
\hline $12 / 24 / 2008$ & 2 & 27 & 38 & 29.5 & 29.5 & 0.79 & 25 \\
\hline $12 / 31 / 2008$ & 2 & 27 & 38 & 28.8 & 28.8 & 0.77 & 25 \\
\hline 1/7/2009 & 2 & 28 & 38 & 15.5 & 15.5 & 0.41 & 25 \\
\hline $1 / 8 / 2009$ & 1 & 28 & 25 & 9.5 & 9.5 & 0.38 & 10 \\
\hline $1 / 14 / 2009$ & 2 & 28 & 38 & 27.9 & 27.9 & 0.74 & 25 \\
\hline $1 / 21 / 2009$ & 2 & 28 & 38 & 25.8 & 25.8 & 0.69 & 25 \\
\hline $1 / 22 / 2009$ & 1 & 28 & 25 & 17.0 & 17.0 & 0.68 & 10 \\
\hline $1 / 28 / 2009$ & 2 & 28 & 38 & 25.0 & 25.0 & 0.67 & 25 \\
\hline 2/4/2009 & 2 & 28 & 38 & 14.0 & 14.0 & 0.37 & 25 \\
\hline $2 / 5 / 2009$ & 1 & 28 & 25 & 6.8 & 6.8 & 0.27 & 10 \\
\hline $2 / 11 / 2009$ & 2 & 28 & 38 & 26.9 & 26.8 & 0.72 & 25 \\
\hline $2 / 18 / 2009$ & 2 & 28 & 38 & 23.8 & 23.8 & 0.63 & 25 \\
\hline 2/19/2009 & 1 & 28 & 25 & 15.0 & 15.0 & 0.60 & 10 \\
\hline $2 / 25 / 2009$ & 2 & 28 & 38 & 25.9 & 25.9 & 0.69 & 25 \\
\hline $3 / 4 / 2009$ & 2 & 28 & 38 & 11.2 & 11.2 & 0.30 & 25 \\
\hline $3 / 5 / 2009$ & 1 & 28 & 25 & 5.5 & 5.5 & 0.22 & 10 \\
\hline $3 / 11 / 2009$ & 2 & 28 & 38 & 24.8 & 24.8 & 0.66 & 25 \\
\hline $3 / 18 / 2009$ & 2 & 28 & 38 & 18.2 & 18.2 & 0.49 & 25 \\
\hline $3 / 19 / 2009$ & 1 & 28 & 25 & 3.0 & 3.0 & 0.12 & 11 \\
\hline $3 / 25 / 2009$ & 2 & 28 & 38 & 23.0 & 23.0 & 0.61 & 25 \\
\hline $4 / 1 / 2009$ & 2 & 21 & 38 & 6.2 & 6.2 & 0.17 & 25 \\
\hline $4 / 2 / 2009$ & 1 & 28 & 25 & 0.0 & 0.0 & 0.00 & 10 \\
\hline 4/8/2009 & 2 & 28 & 38 & 9.4 & 9.4 & 0.25 & 25 \\
\hline $4 / 15 / 2009$ & 2 & 21 & 38 & 5.0 & 5.0 & 0.13 & 25 \\
\hline $4 / 16 / 2009$ & 1 & 28 & 25 & 0.0 & 0.0 & 0.00 & 10 \\
\hline $4 / 22 / 2009$ & 2 & 29 & 75 & 18.2 & 18.2 & 0.24 & 25 \\
\hline $4 / 30 / 2009$ & 1 & 28 & 25 & 0.0 & 0.0 & 0.00 & 10 \\
\hline $5 / 6 / 2009$ & 2 & 29 & 75 & 14.4 & 14.4 & 0.19 & 25 \\
\hline $5 / 14 / 2009$ & 1 & 28 & 25 & 0.0 & 0.0 & 0.00 & 10 \\
\hline $5 / 21 / 2009$ & 2 & 28 & 75 & 13.0 & 13.0 & 0.17 & 25 \\
\hline $5 / 28 / 2009$ & 1 & 28 & 25 & 0.0 & 0.0 & 0.00 & 10 \\
\hline $6 / 4 / 2009$ & 2 & 27 & 75 & 2.8 & 2.8 & 0.04 & 25 \\
\hline $6 / 11 / 2009$ & 1 & 28 & 25 & 0.0 & 0.0 & 0.00 & 10 \\
\hline $6 / 18 / 2009$ & 2 & 28 & 75 & 4.0 & 4.0 & 0.05 & 25 \\
\hline $6 / 25 / 2009$ & 1 & 28 & 25 & 0.0 & 0.0 & 0.00 & 10 \\
\hline 7/1/2009 & 2 & 15 & 38 & 0.3 & 0.3 & 0.01 & 25 \\
\hline $7 / 16 / 2009$ & 2 & 28 & 75 & 2.7 & 2.7 & 0.04 & 25 \\
\hline $8 / 13 / 2009$ & 2 & 28 & 75 & 0.0 & 0.0 & 0.00 & 25 \\
\hline $9 / 10 / 2009$ & 2 & 28 & 75 & 0.0 & 0.0 & 0.00 & 25 \\
\hline $10 / 8 / 2009$ & 2 & 28 & 50 & 0.0 & 0.0 & 0.00 & 25 \\
\hline $11 / 5 / 2009$ & 2 & 28 & 25 & 0.0 & 0.0 & 0.00 & 25 \\
\hline $12 / 3 / 2009$ & 2 & 35 & 25 & 0.0 & 0.0 & 0.00 & 25 \\
\hline $1 / 7 / 2010$ & 2 & 28 & 25 & 0.0 & 0.0 & 0.00 & 25 \\
\hline
\end{tabular}

Note: The table reports data for all 91 auctions over the life of the Term Securities Lending Facility. Terms are in days, amounts are in billions of dollars, par value, and rates are in basis points. 
Table A2. Explaining Whether a Dealer Participates (with Probit Model)

\begin{tabular}{|c|c|c|c|c|c|c|c|c|c|}
\hline & \multicolumn{3}{|c|}{ TSLF Schedule 1} & \multicolumn{3}{|c|}{ TSLF Schedule 2} & \multicolumn{3}{|c|}{ PDCF } \\
\hline & $(1)$ & $(2)$ & (3) & (4) & $(5)$ & $(6)$ & $(7)$ & $(8)$ & (9) \\
\hline Equity return & $\begin{array}{c}-1.774 * * \\
(0.838)\end{array}$ & & $\begin{array}{l}-0.596^{\mathrm{jj}} \\
(1.012)\end{array}$ & $\begin{array}{c}-3.271 * * * \\
(0.907)\end{array}$ & & $\begin{array}{c}-2.502 * * \mathrm{jij} \\
(1.011)\end{array}$ & $\begin{array}{c}-2.721 * * \\
(1.280)\end{array}$ & & $\begin{array}{c}-4.054 * * * \mathrm{ji} \\
(1.429)\end{array}$ \\
\hline 10/Quasi-leverage & & $\begin{array}{c}-2.248 * * \\
(0.910)\end{array}$ & $\begin{array}{c}-1.891 * \mathrm{kj} \\
(1.062)\end{array}$ & & $\begin{array}{c}-2.601 * * * \\
(0.847)\end{array}$ & $\begin{array}{c}-1.089^{\mathrm{ijj}} \\
(0.868)\end{array}$ & & $\begin{array}{l}-0.908 \\
(1.024)\end{array}$ & $\begin{array}{c}1.753^{\mathrm{ij}} \\
(1.149)\end{array}$ \\
\hline Time fixed effects & YES & YES & YES & YES & YES & YES & YES & YES & YES \\
\hline Constant & $\begin{array}{c}0.136 \\
(0.441)\end{array}$ & $\begin{array}{c}1.814 * * * \\
(0.554)\end{array}$ & $\begin{array}{l}1.464 * \\
(0.818)\end{array}$ & $\begin{array}{c}0.155 \\
(0.488)\end{array}$ & $\begin{array}{c}2.606 * * * \\
(0.460)\end{array}$ & $\begin{array}{l}1.022^{*} \\
(0.606)\end{array}$ & $\begin{array}{c}-1.967 * * * \\
(0.574)\end{array}$ & $\begin{array}{l}-0.358 \\
(0.637)\end{array}$ & $\begin{array}{c}-3.329 * * * \\
(1.044)\end{array}$ \\
\hline Observations & 429 & 428 & 428 & 828 & 827 & 827 & 3,918 & 3,916 & 3,916 \\
\hline Pseudo R-squared & 0.206 & 0.235 & 0.239 & 0.281 & 0.247 & 0.289 & 0.211 & 0.115 & 0.235 \\
\hline
\end{tabular}

Notes: The table reports the results of probit participation regressions for the TSLF and PDCF. The TSLF Schedule 1 (Schedule 2) dependent variable is an indicator variable equal to one if a dealer submitted a bid in a Schedule 1 (Schedule 2) auction and zero otherwise. The PDCF dependent variable is an indicator variable equal to one if a dealer borrowed from the PDCF on a given day and zero otherwise. Cumulative equity returns are calculated for each firm from January 2, 2007 to the day preceding each operation. Quasi-leverage is the ratio of a firm's quasi-market value of assets (i.e., the market value of equity plus the book value of debt) to market value of equity as of the day preceding each operation. Standard errors clustered by dealer are reported in parentheses. Coefficients marked ***, **, and * are significant at the $1 \%, 5 \%$ and $10 \%$ levels, respectively. Equity return and quasi-leverage coefficients marked $\mathrm{jjj}$, jj, and $\mathrm{j}$ are jointly significant at the $1 \%, 5 \%$ and $10 \%$ levels, respectively. 
Table A3 Explaining Bid/Borrowing Amounts, Conditional on Participation (with Tobit Model)

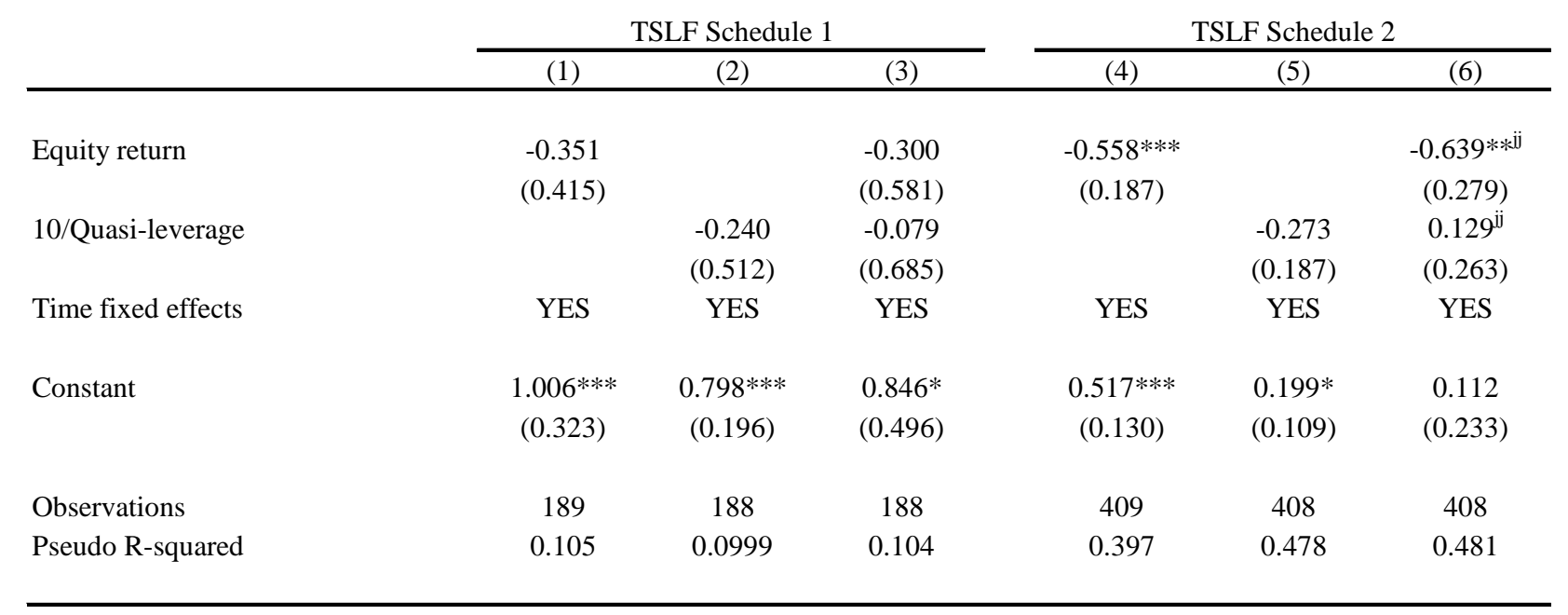

Notes: The table reports the results of Tobit bid amount regressions for the TSLF. The TSLF Schedule 1 (Schedule 2) dependent variable is the ratio of the total amount a dealer bid/borrowed in a given Schedule 1 (Schedule 2) auction to the maximum award amount, and is right-censored at one. The dependent variables are conditional on participation and hence undefined when a dealer does not bid. Cumulative equity returns are calculated for each firm from January 2, 2007 to the day preceding each operation. Quasi-leverage is the ratio of a firm's quasi-market value of assets (i.e., the market value of equity plus the book value of debt) to market value of equity as of the day preceding each operation. Standard errors clustered by dealer are reported in parentheses. Coefficients marked $* * *, * *$, and $*$ are significant at the $1 \%, 5 \%$ and $10 \%$ levels, respectively. Equity return and quasi-leverage coefficients marked $\mathrm{jjj}, \mathrm{jj}$, and $\mathrm{j}$ are jointly significant at the $1 \%, 5 \%$ and $10 \%$ levels, respectively. 
Table A4. Explaining Bid Rates (with Tobit Model)

\begin{tabular}{|c|c|c|c|c|c|c|}
\hline & \multicolumn{3}{|c|}{ TSLF Schedule 1} & \multicolumn{3}{|c|}{ TSLF Schedule 2} \\
\hline & $(1)$ & $(2)$ & (3) & $(4)$ & $(5)$ & $(6)$ \\
\hline Equity return & $\begin{array}{c}-0.376^{*} \\
(0.207)\end{array}$ & & $\begin{array}{l}-0.155^{\mathrm{ijj}} \\
(0.239)\end{array}$ & $\begin{array}{c}-3.174 * * \\
(1.357)\end{array}$ & & $\begin{array}{l}-3.371^{\mathrm{j} j} \\
(2.236)\end{array}$ \\
\hline 10/Quasi-leverage & & $\begin{array}{c}-0.606^{* * * *} \\
(0.174)\end{array}$ & $\begin{array}{c}-0.541 * * \mathrm{ijj} \\
(0.228)\end{array}$ & & $\begin{array}{c}-1.890 * * \\
(0.934)\end{array}$ & $\begin{array}{l}0.261^{\mathrm{jj}} \\
(1.804)\end{array}$ \\
\hline Time fixed effects & YES & YES & YES & YES & YES & YES \\
\hline Constant & $\begin{array}{l}-0.049 \\
(6.526)\end{array}$ & $\begin{array}{c}0.327 * * * \\
(9.497)\end{array}$ & $\begin{array}{c}0.251^{*} \\
(14.798)\end{array}$ & $\begin{array}{l}-0.142 \\
(0.536)\end{array}$ & $\begin{array}{c}1.827 * * * \\
(0.585)\end{array}$ & $\begin{array}{l}-0.329 \\
(1.560)\end{array}$ \\
\hline Observations & 189 & 188 & 188 & 409 & 408 & 408 \\
\hline Pseudo R-squared & 0.0861 & 0.0916 & 0.0921 & 0.178 & 0.149 & 0.178 \\
\hline
\end{tabular}

Notes: The table reports results of Tobit bid rate regressions for the TSLF. The dependent variable is the bid rate, which is left-censored at 0.1 for Schedule 1 auctions and 0.25 for Schedule 2 auctions. If a dealer submitted two bids in an auction, then the dependent variable equals the average bid rate weighted by bid amount. The dependent variable is undefined if a dealer did not submit any bids. Cumulative equity returns are calculated for each firm from January 2, 2007 to the day preceding each auction. Quasi-leverage is the ratio of a firm's quasi-market value of assets (i.e., the market value of equity plus the book value of debt) to market value of equity as of the day preceding each auction. Standard errors clustered by dealer are reported in parentheses. Coefficients marked $* * *, * *$, and $*$ are significant at the $1 \%, 5 \%$ and $10 \%$ levels, respectively. Equity return and quasi-leverage coefficients marked $\mathrm{jjj}$, jj, and $\mathrm{j}$ are jointly significant at the $1 \%, 5 \%$ and $10 \%$ levels, respectively. 


\section{Table A5. Effects of Dynamic MMF Non-Fed Eligible Collateral}

\begin{tabular}{|c|c|c|c|c|c|c|c|c|}
\hline \multirow[b]{2}{*}{ Dependent Variable: Unconditional Bid Amount } & \multicolumn{4}{|c|}{ TSLF2 } & \multicolumn{4}{|c|}{ PDCF } \\
\hline & $(1)$ & (2) & (3) & (4) & $(5)$ & $(6)$ & (7) & $(8)$ \\
\hline Equity return & $\begin{array}{c}-0.450^{* * *} \\
(0.111)\end{array}$ & $\begin{array}{c}-0.439 * * * \\
(0.118)\end{array}$ & & & $\begin{array}{c}-0.327 * * \\
(0.117)\end{array}$ & $\begin{array}{l}-0.234 \\
(0.148)\end{array}$ & & \\
\hline Equity return* non-Fed eligible & & $\begin{array}{l}-0.098 \\
(0.303)\end{array}$ & & & & $\begin{array}{l}-0.874 \\
(0.921)\end{array}$ & & \\
\hline 10/Quasi-leverage & & & $\begin{array}{c}-0.248 * * \\
(0.096)\end{array}$ & $\begin{array}{c}-0.227 * * \\
(0.095)\end{array}$ & & & $\begin{array}{l}-0.102 \\
(0.068)\end{array}$ & $\begin{array}{l}-0.024 \\
(0.058)\end{array}$ \\
\hline 10/Quasi-leverage $*$ non-Fed eligible & & & & $\begin{array}{l}-0.338 \\
(0.830)\end{array}$ & & & & $\begin{array}{l}-1.389 \\
(1.052)\end{array}$ \\
\hline Dynamic MMF non-Fed eligible & $\begin{array}{c}0.417 * * \\
(0.152)\end{array}$ & $\begin{array}{l}0.371^{*} \\
(0.173)\end{array}$ & $\begin{array}{c}0.491 * * \\
(0.194)\end{array}$ & $\begin{array}{c}0.628 \\
(0.430)\end{array}$ & $\begin{array}{c}0.305 \\
(0.197)\end{array}$ & $\begin{array}{l}-0.080 \\
(0.271)\end{array}$ & $\begin{array}{c}0.354 \\
(0.217)\end{array}$ & $\begin{array}{c}0.944 \\
(0.658)\end{array}$ \\
\hline Time fixed effects & YES & YES & YES & YES & YES & YES & YES & YES \\
\hline Constant & $\begin{array}{c}0.162 \\
(0.118)\end{array}$ & $\begin{array}{c}0.169 \\
(0.117)\end{array}$ & $\begin{array}{c}0.412 * * * \\
(0.109)\end{array}$ & $\begin{array}{c}0.411^{* * * *} \\
(0.108)\end{array}$ & $\begin{array}{c}-0.174 * * \\
(0.078)\end{array}$ & $\begin{array}{c}-0.130 * \\
(0.069)\end{array}$ & $\begin{array}{l}-0.010 \\
(0.046)\end{array}$ & $\begin{array}{l}-0.029 \\
(0.060)\end{array}$ \\
\hline Observations & 753 & 753 & 752 & 752 & 6,156 & 6,156 & 6,147 & 6,147 \\
\hline Adjusted R-squared & 0.393 & 0.392 & 0.346 & 0.346 & 0.248 & 0.254 & 0.215 & 0.226 \\
\hline
\end{tabular}

Notes: The table reports results of OLS bid amount regressions for the PDCF and TSLF2. The TSLF Schedule 2 dependent variable is the ratio of the total amount a dealer bid in a given Schedule 2 auction to the maximum award amount. The PDCF dependent variable is the amount borrowed from the PDCF on a given day, in tens of billions of dollars. Cumulative equity returns are calculated for each firm from January 2, 2007 to the day preceding each operation. Quasi-leverage is the ratio of a firm's quasi-market value of assets (i.e., the market value of equity plus the book value of debt) to market value of equity as of the day preceding each operation. MMF Non-Fed Eligible is the share of collateral each dealer pledged to money market funds that is not U.S. Treasury, agency debt, or agency mortgage-backed securities in the three-month window before each auction. Coefficients marked $* * *, * *$, and $*$ are significant at the $1 \%, 5 \%$ and $10 \%$ levels, respectively. 
Table A6. Explaining Bid/Borrowing Amounts (Unconditional on Participation)

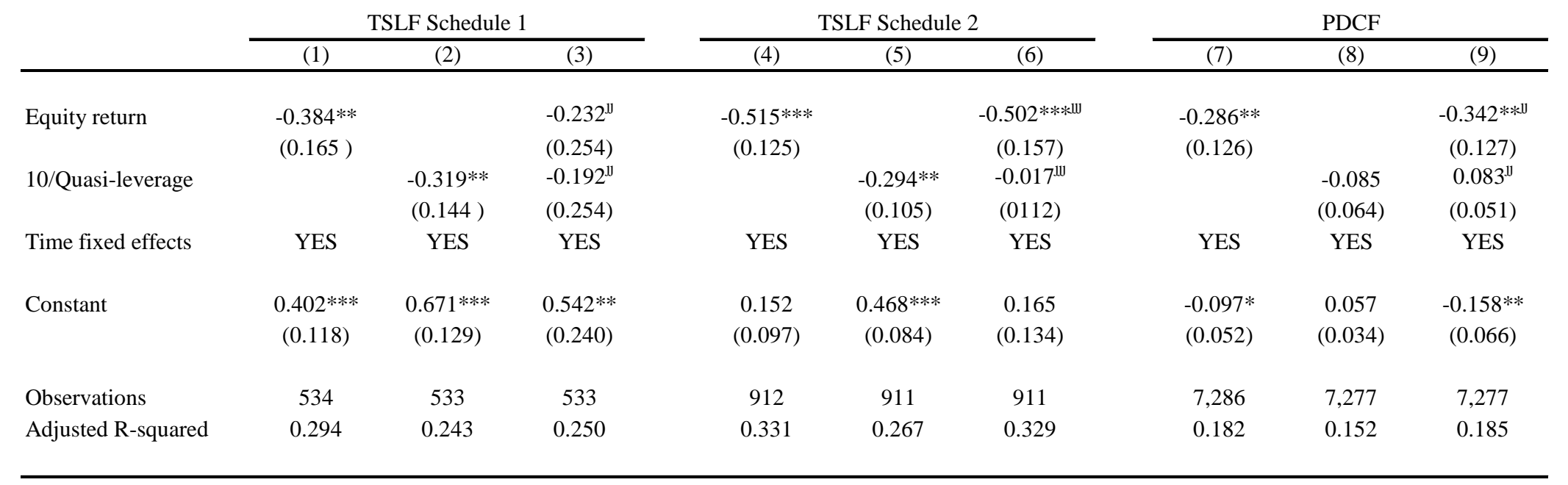

Notes: The table reports the results of OLS bid/borrowing amount regressions for the TSLF and PDCF. The TSLF Schedule 1 (Schedule 2) dependent variable is the ratio of the total amount a dealer bid in a given Schedule 1 (Schedule 2) auction to the maximum award amount. The PDCF dependent variable is the amount borrowed from the PDCF on a given day, in tens of billions of dollars. The dependent variables are not conditional on participation and are equal to 0 when a dealer does not bid (TSLF) or borrow (PDCF). Cumulative equity returns are calculated for each firm from January 2, 2007 to the day preceding each operation. Quasi-leverage is the ratio of a firm's quasi-market value of assets (i.e., the market value of equity plus the book value of debt) to market value of equity as of the day preceding each operation. Standard errors clustered by dealer are reported in parentheses. Coefficients marked $* * *, * *$, and $*$ are significant at the $1 \%, 5 \%$ and $10 \%$ levels, respectively. Equity return and quasi-leverage coefficients marked jjj, jj, and $\mathrm{j}$ are jointly significant at the $1 \%, 5 \%$ and $10 \%$ levels, respectively. 
Table A7. Explaining Dealer Participation with Prior Participation

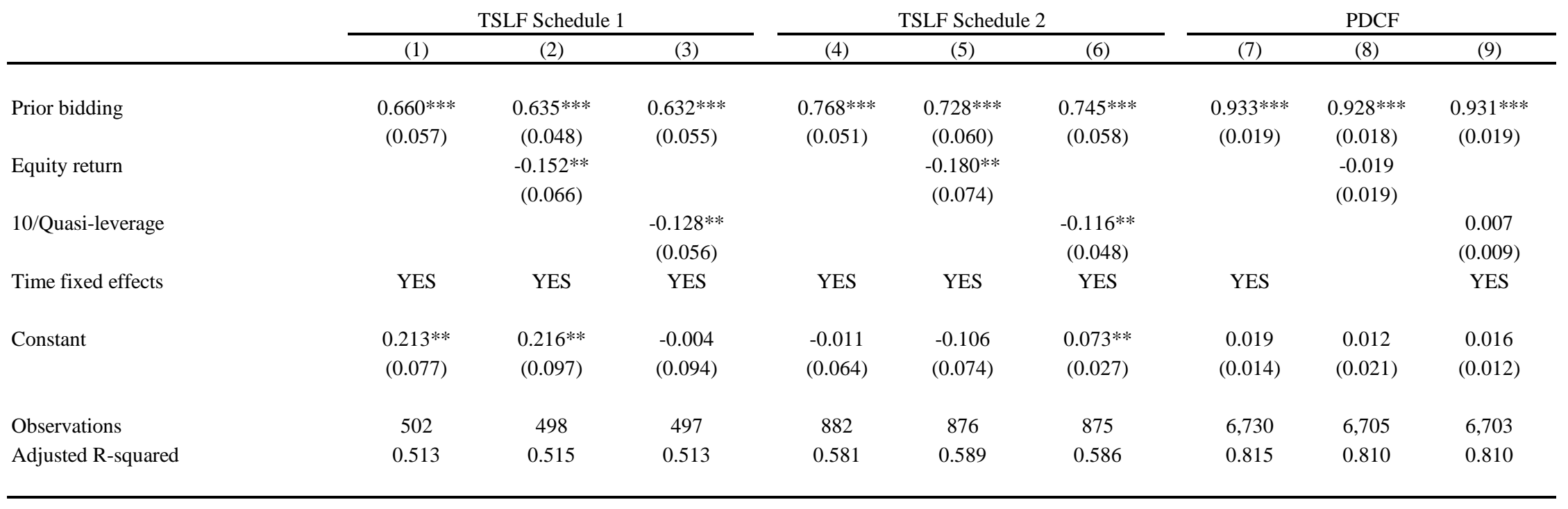

Notes: The table reports the results of OLS participation regressions for the TSLF and PDCF. The TSLF Schedule 1 (Schedule 2) dependent variable is an indicator variable equal to one if a dealer submitted a bid in a Schedule 1 (Schedule 2) auction and zero otherwise. The PDCF dependent variable is an indicator variable equal to one if a dealer borrowed from the PDCF on a given day and zero otherwise. Prior bidding is defined as the number of operations in which a dealer participated over the previous 20 business days, divided by the number of operations over those days. Cumulative equity returns are calculated for each firm from January 2, 2007 to the day preceding each operation. Quasi-leverage is the ratio of a firm's quasi-market value of assets (i.e., the market value of equity plus the book value of debt) to market value of equity as of the day preceding each operation. Standard errors clustered by dealer are reported in parentheses. Coefficients marked $* * *, * *$, and $*$ are significant at the $1 \%, 5 \%$ and $10 \%$ levels, respectively. 